\title{
Organocatalyzed enantioselective desymmetrization of aziridines and epoxides
}

Ping-An Wang

\author{
Review \\ Address: \\ Department of Medicinal Chemistry, School of Pharmacy, Fourth \\ Military Medical University, Changle Xilu 17, Xi-An, 710032, P. R. \\ China \\ Email: \\ Ping-An Wang - ping_an1718@outlook.com \\ Keywords: \\ aziridine; desymmetrization; enantioselectivity; epoxide; \\ organocatalysis
}

Beilstein J. Org. Chem. 2013, 9, 1677-1695.

doi:10.3762/bjoc.9.192

Received: 05 June 2013

Accepted: 19 July 2013

Published: 15 August 2013

Associate Editor: S. You

() 2013 Wang; licensee Beilstein-Institut.

License and terms: see end of document.

\begin{abstract}
Enantioselective desymmetrization of meso-aziridines and meso-epoxides with various nucleophiles by organocatalysis has emerged as a cutting-edge approach in recent years. This review summarizes the origin and recent developments of enantioselective desymmetrization of meso-aziridines and meso-epoxides in the presence of organocatalysts.
\end{abstract}

\section{Introduction}

The high demand of enantiopure organic compounds in the fine chemical industry gives impetus to the development of chiral technologies. Among them, the catalytic asymmetric synthesis represents the state of the art in organic chemistry [1]. Over the past four decades, the asymmetric synthesis based on transitionmetal catalyzed reactions has given rise to a variety of significant achievements both in academic and industrial chemistry $[2,3]$. Desymmetrization is the modification of a molecule which results in the loss of symmetry elements such as a mirror plane, a center of inversion or a rotation-reflection axis (Figure 1). Usually, a prochiral or meso-molecule can be converted into a chiral molecule in a single step [4-6] in the presence of chiral catalysts. Therefore, enantioselective desymmetrization is regarded as a very powerful strategy for producing a large amount of chiral compounds from readily available achiral substrates. The past decade witnessed the renaissance and the golden age of organocatalyzed reactions [7-9]. Aziridines and epoxides are quite reactive due to the large tension of their three-membered ring system. The enantioselective ring-opening of aziridines [10-12] or epoxides [13-15] provides facile access to various chiral amines and alcohols and their derivatives with two adjacent stereogenic centers, which

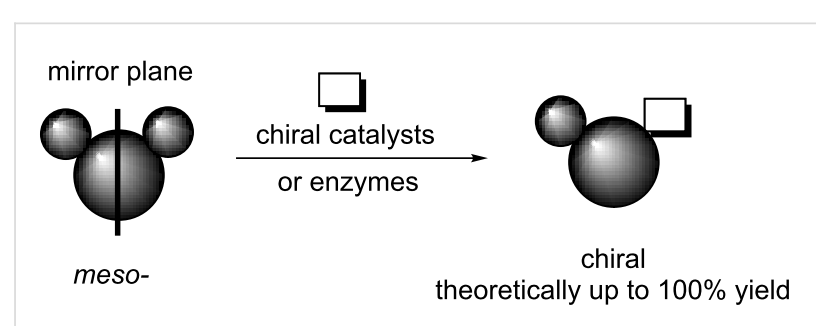

Figure 1: The catalyzed enantioselective desymmetrization. 
are widely used as building blocks in pharmaceutical and organic synthesis. The enantioselective catalytic desymmetrization of meso-aziridines and meso-epoxides by metal-based Lewis acids cooperating with chiral ligands has been well established [16-28]. However, the enantioselective desymmetrization of meso-aziridines and meso-epoxides catalyzed by small chiral organic molecules has only emerged in recent years. The goal of this review is to give a comprehensive overview on newly developed strategies in the field of organocatalyzed enantioselective desymmetrization of meso-aziridines and mesoepoxides.

\section{Review}

\section{Organocatalyzed enantioselective desym- metrization of meso-aziridines}

Many examples of the ring-opening of aziridines by various carbon $[29,30]$, nitrogen [31,32], oxygen [33,34], sulfur [35,36] and halogen [37-39] nucleophilic reagents in the presence of catalytic amounts of small acids and bases such as $\mathrm{BF}_{3} \cdot \mathrm{Et}_{2} \mathrm{O}$, $\mathrm{AcOH}, \mathrm{TsOH}, \mathrm{TFA}, \mathrm{PBu}_{3}$, TMEDA, TBAF, $\mathrm{Bu}_{4} \mathrm{NHSO}_{4}$, pyridine $N$-oxide, and $N$-heterocyclic carbenes were published. However, the enantioselective ring-opening of meso-aziridines in the presence of chiral organocatalysts (OC) has emerged as a research field only in recent years. The organocatalysts utilized in these processes are diverse in their structural features including cinchona alkaloid derivatives, chiral phosphoric acids, chiral amino alcohols, chiral thioureas, chiral guanidines, and chiral 1,2,3-triazolium chlorides. In this review, the research work of enantioselective desymmetrization of meso-aziridines is organized into sections according to the employed organocatalysts.

\section{Cinchona alkaloid derivatives}

The first organocatalytic enantioselective desymmetrization of meso-aziridines was discovered by Hou and co-workers in 2007 [40] with various arylthiols as nucleophiles in $\mathrm{CCl}_{4}$ at $0{ }^{\circ} \mathrm{C}$ in the presence of cinchonine-derived phase-transfer catalysts (PTCs, Figure 2, OC-1 to OC-6). The substituent on the bridgehead nitrogen of cinchona alkaloids has a great impact on the enantioselectivity of the reactions. The catalyst OC-2 with 9-anthracenylmethyl on the bridgehead nitrogen is more efficient than other cinchona alkaloid-derived catalysts for the desymmetrization of meso- $N$-tosylaziridine (tosyl $=\mathrm{Ts}$ ) as it affords the corresponding chiral $N$-Ts thioamines (Scheme 1, 1 to 9 ,) in high yield (85\%) and satisfactory enantioselectivity (73\% ee). The OC-4 and OC-5 with a protecting group on $9-\mathrm{OH}$ decreased the enantioselectivity dramatically. In the presence of OC-6, when $p$-nitrophenylsulfonylaziridine (Ns-aziridine) was employed as substrate, the corresponding $N$-Ns thioamine $\mathbf{8}$ was obtained in quantitative yield but with moderate enantioselectivity $(55 \%$ ee). The need of two equiva- lents (equiv) of $\mathrm{CsOH} \cdot \mathrm{H}_{2} \mathrm{O}$ as a base in the procedure limited its application in organic synthesis.

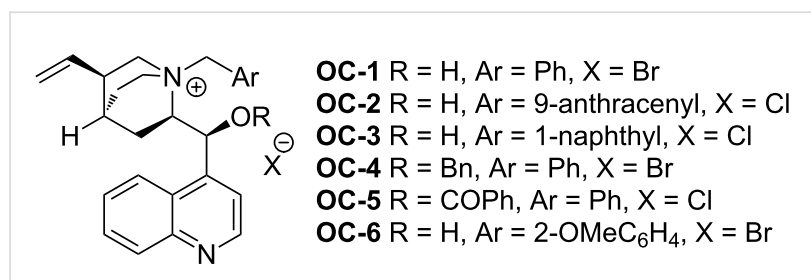

cinchonine-derived PTCs<smiles>C=CC1CN2CCC1C[C@H]2[C@H](O)c1ccnc2ccccc12</smiles>

OC-9 (cinchonidine)

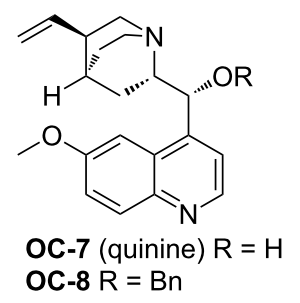

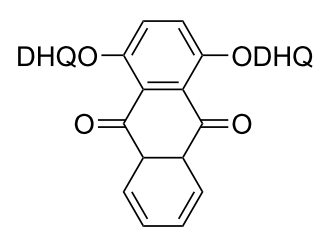

$\mathrm{OC}-10(\mathrm{DHQ})_{2} \mathrm{AQN}$ $\mathrm{DHQ}=$ dihydroquinine

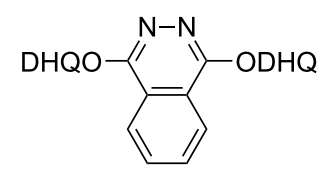

OC-11 (DHQ) $)_{2}$ PHAL
Figure 2: Cinchona alkaloid-derived catalysts OC-1 to OC-11.

$\mathrm{Wu}$ and co-workers have established the enantioselective ringopening of meso-aziridines with arylthiols by using various quinine derivatives (OC-7 to $\mathbf{O C}-11)$ as organocatalysts (Scheme 1) [41]. It was found that the desymmetrization performed well in $\mathrm{CHCl}_{3}$ in the presence of $10 \mathrm{~mol} \%$ of quinine (OC-7) at room temperature. The $\beta$-amino sulfides were obtained in high yields (up to $85 \%$ ) and with moderate enantioselectivities (up to $72 \%$ ee). However, OC-10 and OC-11 afforded extremely disappointing results for desymmetrization and the corresponding $\beta$-amino sulfide was obtained nearly racemic ( $3 \%$ ee). The usage of Boc for the $N$-protected group in aziridine resulted in no enantioselectivity under the optimum conditions.

The organocatalytic enantioselective ring-opening of $\mathrm{N}$-protected aziridines by $\beta$-ketoesters by means of cinchona alkaloidderived PTCs (Figure 3, OC-12 to OC-19) for producing $\gamma$-amino acid derivatives with one stereogenic quaternary carbon has been independently developed by Dixon [42] and Jørgensen's group [43]. Dixon and co-workers discovered that OC-16 bearing bulky substituents both on the 9-O atom and the bridgehead nitrogen afforded excellent enantioselectivity of desirable products (Scheme 2, 13 to $\mathbf{1 8}$, up to $97 \%$ ee) with $50 \%$ 


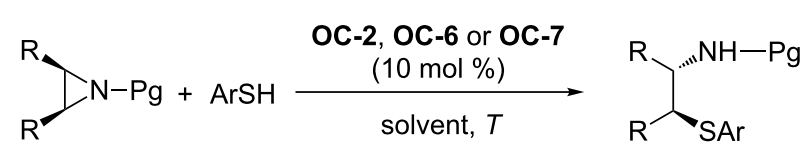

$\mathrm{Pg}=$ protecting group $=\mathrm{Ts}$ or $\mathrm{Ns}$<smiles>[AsH3]NC1CCCCC1Sc1ccccc1</smiles>

1

OC-2 85\%, 73\% ee OC-6 99\%, 28\% ee OC-7 $85 \%, 72 \%$ ee OC-7 $52 \%, 50 \%$ ee

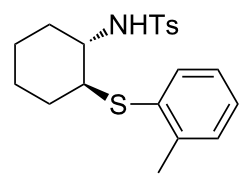

2

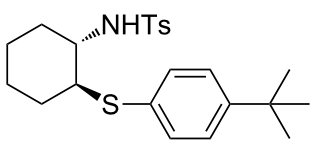

3

OC-6 99\%, 58\% ee OC-7 $80 \%, 32 \%$ ee

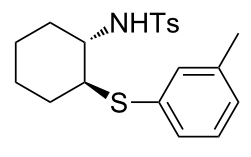

4

OC-2 98\%, 6\% ee OC-6 99\%, $28 \%$ ee

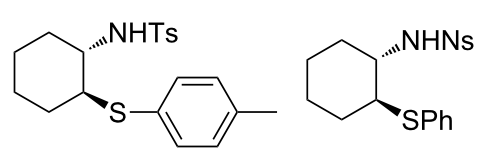

5

6

OC-2 99\%, 45\% ee OC-2 99\%, 55\% ee OC- $699 \%, 52 \%$ ee OC- $699 \%, 43 \%$ ee<smiles>[AsH2]NC1CC=CCC1[SbH2]</smiles>

7

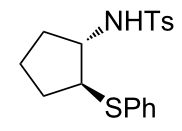

8<smiles></smiles>

9

OC-2 $88 \%, 72 \%$ ee OC-2 $80 \%, 40 \%$ ee OC-2 $92 \%, 44 \%$ ee OC-6 99\%, 66\% ee<smiles>Clc1ccccc1S[C@H]1CCCC[C@H]1N[SbH3]</smiles>

10<smiles>SN[C@H]1CCCC[C@@H]1Sc1ccc(Cl)cc1</smiles>

11<smiles>Cc1ccc(C(C)(C)C)cc1SC1CCCCC1NP</smiles>

12

OC-7 $71 \%, 42 \%$ ee OC-7 $82 \%, 56 \%$ ee OC-7 $53 \%, 63 \%$ ee

Scheme 1: The enantioselective desymmetrization of meso-aziridines in the presence of selected Cinchona alkaloid-derived catalysts<smiles>C=CC1CN2CCC1CC2C(OCc1ccccc1)c1ccnc2ccc(O)cc12</smiles>

OC-12

$$
\mathrm{OC}-13 \mathrm{R}=\mathrm{Ph}, \mathrm{R}^{\prime}=\text { allyl, } \mathrm{X}=\mathrm{Br}
$$$$
\text { OC-14 R = An, } R^{\prime}=\mathrm{H}, X=\mathrm{Cl}
$$

OC-15 R = An, $R^{\prime}=$ allyl, $X=C l$<smiles>[R]C(=O)c1ccnc2ccccc12</smiles>

$$
\text { OC-17 R = H }
$$

OC-18 $R=$ allyl<smiles>C=CC1CN2CCC1C[C@H]2C(NC(=O)Nc1cc(C(F)(F)F)cc(C(F)(F)F)c1)c1ccnc2ccccc12</smiles>

OC-19

Figure 3: Cinchona alkaloid-derived catalysts OC-12 to OC-19.

aqueous $\mathrm{K}_{2} \mathrm{HPO}_{4}$ as base. However, under the same conditions, the PTCs with a free 9-OH (OC-17) led to $\mathbf{1 3}$ in low yields and enantioselectivities (21\% ee). The urea catalyst OC-19 proved to be very inefficient and afforded $\mathbf{1 3}$ in $10 \%$ yield with $6 \%$ ee.

By shifting the $N$-protecting group in aziridines from $o$-(trifluoromethyl)benzenesulfonyl to Ts, Jørgensen and colleagues found that excellent enantioselectivities (up to $97 \%$ ee) of the ring-opening products (Scheme 3, 19 to 27) were obtained by using $\mathrm{OC}-16$ as a catalyst, $33 \mathrm{wt} \%$ aqueous $\mathrm{K}_{2} \mathrm{CO}_{3}$ as a base

and a low reaction temperature of $-20^{\circ} \mathrm{C}$. This afforded perfect enantioselectivity $(99 \%$ ee) of compound 19 , but at the sacrifice of the chemical yield (decrease to $21 \%$ ). The $N$-Boc and $\mathrm{N}$-Cbz protected meso-aziridines yielded the product in trace amounts under the optimum conditions.

\section{Chiral phosphoric acids}

An elegant enantioselective desymmetrization of mesoaziridines catalyzed by chiral phosphoric acids OC-20 and OC-21 as catalysts was carried out by Antilla [44] and co-workers (Figure 4). When a bis(3,5-trifluoromethyl)benzoyl group was used for the $\mathrm{N}$-activation of meso-aziridines, 1,2-azidoamides (Scheme 4, 28 to 36) were obtained in excellent yields (up to 97\%) and enantioselectivities (up to $95 \%$ ee) by using $\mathrm{TMSN}_{3}$ as a nucleophile in the presence of $10 \mathrm{~mol} \%$ of OC-20 or OC-21 in 1,2-dichloroethane (DCE) at room temperature. Interestingly, tetrabutylammonium azide or $\mathrm{NaN}_{3}$ were unreactive as a nucleophile under the same conditions, so the presence of the trimethylsilyl group is crucial to this ringopening reaction. A proposed mechanism was based on NMR spectroscopic investigations as depicted in Figure 5. In the first step of the reaction, the active catalyst was formed by the displacement of the azide to produce $\mathrm{HN}_{3}$ and the chiral silane $\mathbf{A}$. The latter activates the aziridine by means of coordinating to the carbonyl functionality of the aziridine to afford intermediate $\mathbf{B}$. Species $\mathbf{B}$ was then attacked by $\mathrm{HN}_{3}$, resulting in $\mathbf{C}$ and the release of phosphoric acid. Compound $\mathbf{C}$ can be readily decomposed on silica gel to form the final product. Antilla and co-workers have also shown the enantioselective desymmetriza- 


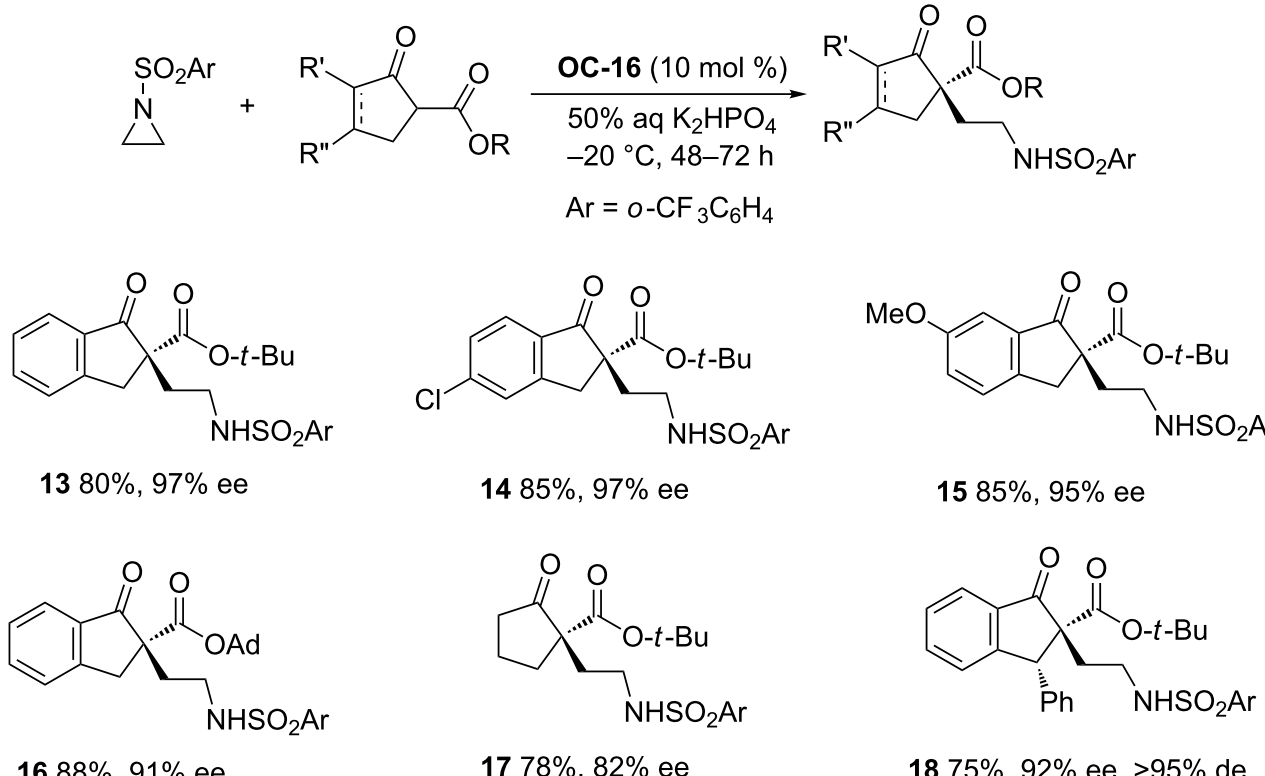

$1688 \%, 91 \%$ ee

$1778 \%, 82 \%$ ee

$1875 \%, 92 \%$ ee, $>95 \%$ de

Scheme 2: The enantioselective ring-opening of aziridines in the presence of OC-16.

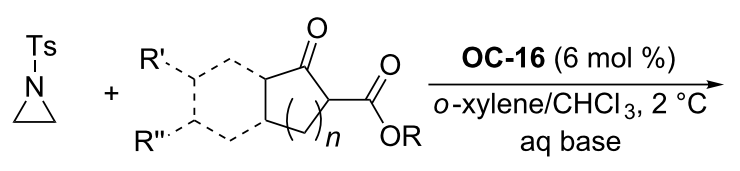

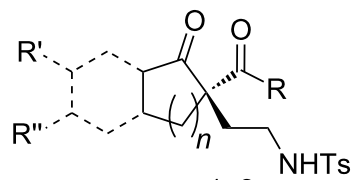<smiles>CC(C)OC(=O)[C@]1(CCNC(F)(F)F)Cc2ccccc2C1=O</smiles>

19

$\mathrm{K}_{2} \mathrm{CO}_{3}(33 \%), 87 \%, 87 \%$ ee $\mathrm{K}_{2} \mathrm{HPO}_{4}(50 \%), 84 \%, 87 \%$ ee<smiles>COc1cc2c(cc1OC)C(=O)[C@@](CCN[18F])(C(=O)OC(C)(C)C)C2</smiles>

23

$\mathrm{K}_{2} \mathrm{CO}_{3}(33 \%), 86 \%, 90 \%$ ee<smiles>CCCCC1(C(=O)OCC)Cc2cc(Cl)ccc2C1=O</smiles>

20

$\mathrm{K}_{2} \mathrm{CO}_{3}(33 \%), 79 \%, 87 \%$ ee $\mathrm{K}_{2} \mathrm{HPO}_{4}(50 \%), 83 \%, 93 \%$ ee<smiles>CC(C)(C)OC(=O)[C@]1(CCN[18F])CCc2ccccc2C1=O</smiles>

21

$\mathrm{NaOH}(10 \%), 0 \%$ ee $\mathrm{K}_{2} \mathrm{HPO}_{4}(50 \%), 0 \%$ ee<smiles>CCCCC1(C(=O)OCC)Cc2cc(OC)ccc2C1=O</smiles>

22<smiles>COC(=O)C1(CCNS)Cc2ccccc2C1=O</smiles>

24

$\mathrm{K}_{2} \mathrm{HPO}_{4}(50 \%)$ $89 \%, 70 \%$ ee<smiles>CCCCCCCCOC(=O)C1(CCCCCC)C(=O)Cc2ccccc21</smiles>

25

$\mathrm{K}_{2} \mathrm{HPO}_{4}(50 \%), \mathrm{rt}$ $74 \%, 76 \%$ ee<smiles>CC(C)(C)OC(=O)[C@]1(CCN[I+])CCCC1=O</smiles>

26

$\mathrm{K}_{3} \mathrm{PO}_{4}(50 \%)$ $53 \%, 77 \%$ ee<smiles>CCCCCC(CCN)(C(=O)OCC)C(=O)c1ccccc1</smiles>

27

$\mathrm{K}_{3} \mathrm{PO}_{4}(50 \%)$

$82 \%, 23 \%$ ee

Scheme 3: OC-16 catalyzed enantioselective ring-opening of aziridines.

tion of meso-aziridines with functionalized mercaptans in the presence of $(S)$-VAPOL in ether at $r$ to afford $\beta$ - $(N$-acylamino)phenyl thioethers in good yields and ee's [45].

By using $10 \mathrm{~mol} \%$ of commercially available chiral phosphoric acid OC-21 as a catalyst, Lattanzi [46] and colleagues have developed a facile desymmetrization of meso- $N$-acylaziridines with $\mathrm{Me}_{3} \mathrm{SiSPh}$ to produce $\beta$ - $(N$-acylamino)phenyl thioethers (Scheme 5, 37 to 44) in high enantioselectivities (78-99\% ee). Interestingly, the aziridines with a six-membered ring were desymmetrized to give the corresponding thioethers in excellent yields and enantioselectivities 
<smiles>[R]C(N)C([R])NC(=O)c1cc(C(F)(F)F)cc(C(F)(F)F)c1</smiles><smiles>NC1CCCCC1NC(=O)c1cc(C(F)(F)F)cc(C(F)(F)F)c1</smiles>

28

OC-20 90\%, 94\% ee OC-21 97\%, 95\% ee<smiles>NC1CC=CCC1NC(=O)c1cc(C(F)(F)F)cc(C(F)(F)F)c1</smiles>

29

OC-20 55\%, 91\% ee OC-21 $84 \%$, 92\% ee<smiles>NC1CCCCCC1NC(=O)c1cc(C(F)(F)F)cc(C(F)(F)F)c1</smiles>

30

OC-21 $72 \mathrm{~h}, 95 \%, 69 \%$ ee OC-21 $91 \mathrm{~h}, 64 \%, 91 \%$ ee<smiles>NC1CCC[C@H]1NC(=O)c1cc(C(F)(F)F)cc(C(F)(F)F)c1</smiles>

31

OC-21 $68 \%, 84 \%$ ee<smiles>CC(N)C(C)NC(=O)c1cc(C(F)(F)F)cc(C(F)(F)F)c1</smiles>

32

33

34

35

36

OC-21 90\%, 70\% ee OC-21 88\%, 86\% ee $\quad$ OC-21 95\%, 83\% ee $\quad$ OC-21 $49 \%, 87 \%$ ee $\quad$ OC-21 $94 \%, 71 \%$ ee<smiles>O=P(O)(O)Oc1c(-c2ccccc2)c(-c2ccccc2)cc2ccccc12</smiles>

OC-20 $(R)$-VANOL<smiles>O=P(O)(Oc1ccccc1)Oc1c(-c2ccccc2)cc2ccc3ccccc3c2c1-c1c(-c2ccccc2)cc2ccc3ccccc3c2c1-c1ccccc1</smiles>

OC-21

(R)-VAPOL
Figure 4: The chiral phosphoric acids catalysts OC-20 and OC-21

when the molar ratio of aziridine/nucleophile/catalyst is $1.0: 1.5: 0.1$. For the unreactive acyclic and seven-membered ring aziridines, the good enantioselectivities were obtained under the reverse ratio of the reagents.

Della Sala's group [47] has demonstrated the first example of a meso-aziridine desymmetrization with selenium nucleophiles to produce chiral $\beta$-aminoselenides in high enantioselectivities (up to $99 \%$ ee). Surprisingly, when the sterically hindered air-stable selenosilane $t-\mathrm{BuMe}_{2} \mathrm{SiSePh}$ was used as a sole nucleophile for desymmetrization of meso- $N$-acylaziridines in the presence of 10 mol \% of chiral phosphoric acid OC-21, the good conversions and enantioselectivities were accomplished in toluene but with a very long reaction time (usually up to 4 days). The

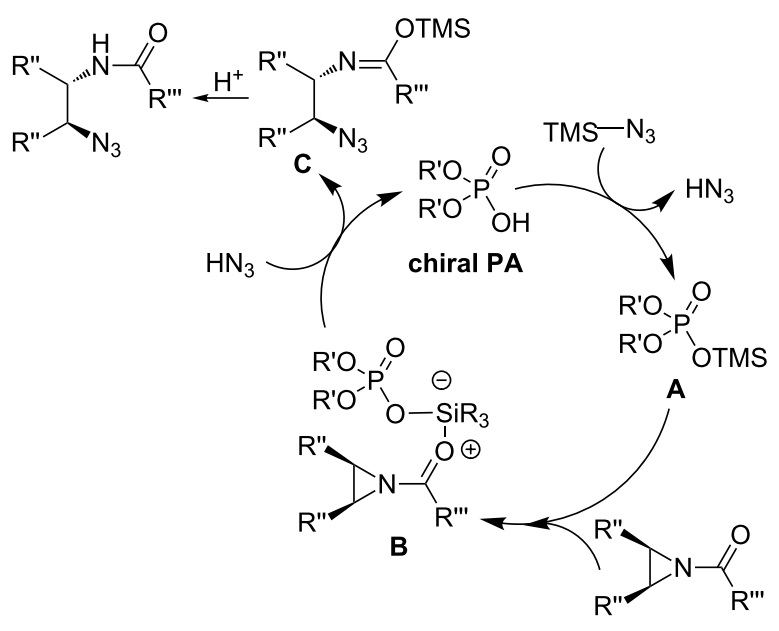

Figure 5: The proposed mechanism for chiral phosphorous acidinduced enantioselctive desymmetrization of meso-aziridines (chiral $\mathrm{PA}=$ OC-21).

desymmetrization of meso- $N$-acylaziridines by the less sterically hindered selenosilane $\mathrm{Me}_{3} \mathrm{SiSePh}$ under the same conditions can be completed in several hours with good yields but moderate ee's. According to the proposed mechanism, the formation of a small amount of $\mathrm{PhSeH}$ was involved in the induction step of the catalytic cycle and it acted as the actual nucleophile for the desymmetrization. In such a way a modified protocol based on the use of a combination of $\mathrm{Me}_{3} \mathrm{SiSePh}$ and $\mathrm{PhseH}$ as a nucleophile was developed. This modification 


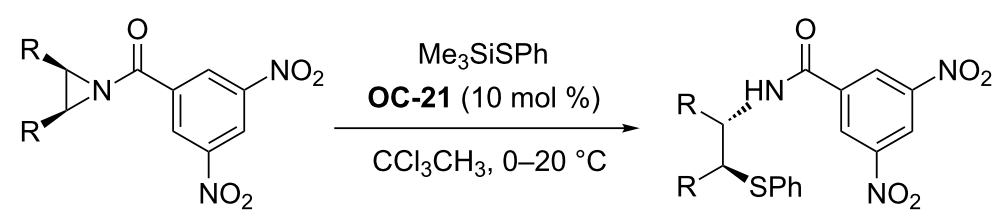<smiles>O=C(NC1CC=CCC1Sc1ccccc1)c1cc(C(=O)NC2CCCCC2Sc2ccccc2)cc([N+](=O)[O-])c1</smiles>

37 97\%, 93\% ee

$3890 \%, 83 \%$ ee<smiles>O=C(N[C@H]1Cc2ccccc2C[C@H]1c1ccccc1)c1cc([N+](=O)[O-])cc([N+](=O)[O-])c1</smiles>

$4168 \%, 99 \%$ ee<smiles>CC(NC(=O)c1cc([N+](=O)[O-])cc([N+](=O)[O-])c1)[C@H](C)c1ccccc1</smiles>

$4288 \%, 94 \%$ ee
$3988 \%, 78 \%$ ee

Scheme 5: OC-21 catalyzed enantioselective desymmetrization of meso-aziridines by $\mathrm{Me}_{3} \mathrm{SiSPh}$

proved to be very valuable and the desymmetrization can be accomplished within several hours to afford the chiral $\beta$-aminoselenides (Scheme 6, 45 to 52) in both high yields (up to $97 \%$ ) and enantioselectivities (up to $97 \%$ ee).

Recently, Della Sala [48] has re-examined the enantioselective desymmetrization of meso-aziridines with various silylated reagents $\left(\mathrm{Me}_{3} \mathrm{SiN}_{3}, \mathrm{Me}_{3} \mathrm{SiSMe}, \mathrm{Me}_{3} \mathrm{SiSPh}, \mathrm{Me}_{3} \mathrm{SiSBn}\right.$, $\mathrm{Me}_{3} \mathrm{SiNCS}$ and $\mathrm{Me}_{3} \mathrm{SiSePh} / \mathrm{PhSeH}$ ) by chiral phosphoric acid OC-21. It was found that both purchased and synthetic OC-21 exhibited high catalytic activities and enantioselective inductions in the desymmetrization of meso-aziridines. Samples of OC-21 were washed with aq $\mathrm{HCl}$ to generate metal-free chiral phosphoric acid OC-21, which was reused as the catalyst, and the corresponding ring-opening products were obtained in moderate yields as racemates. By using a 1:1 mixture of calcium and magnesium phosphate salts of $\mathbf{O C - 2 1}$ as the catalyst, the corresponding ring-opening product $\mathbf{2 8}$ was produced in $94 \%$ yield and $91 \%$ ee. Therefore, calcium and magnesium phosphate salts of $\mathbf{O C}-\mathbf{2 1}$ proved to be the true catalysts in

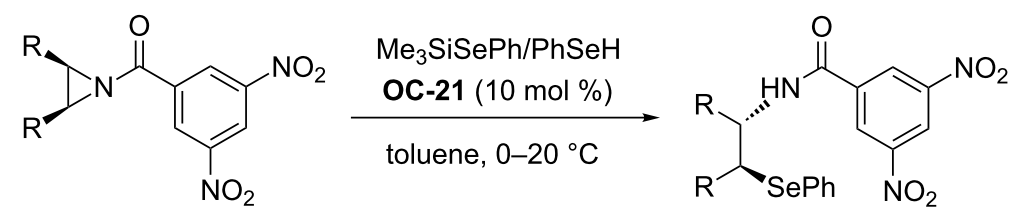<smiles>CS(=O)(=O)[C@H]1CCCC[C@@H]1NC(=O)c1cc([N+](=O)[O-])cc([N+](=O)[O-])c1</smiles><smiles>O=C(N[C@H]1CCCC[C@@H]1Sc1ccccc1)c1cc(C(=O)N[C@H]2CCC[C@H]2[SeH]c2ccccc2)cc([N+](=O)[O-])c1</smiles>

45 94\%, 97\% ee

$4673 \%, 95 \%$ ee

$4746 \%, 96 \%$ ee

48 90\%, 96\% ee

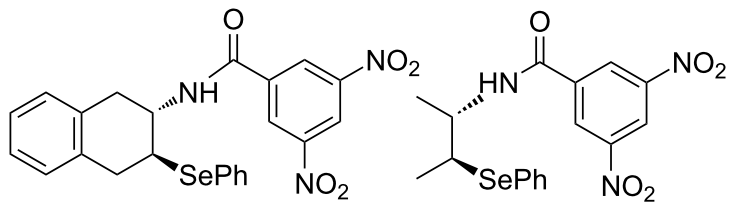

$4974 \%$, $98 \%$ ee

$5072 \%, 92 \%$ ee<smiles>O=C(N[C@H](c1ccccc1)C(c1ccccc1)c1ccccc1)c1cc([N+](=O)[O-])cc([N+](=O)[O-])c1</smiles>

51 97\%, 72\% ee<smiles>CCCC(CCC)[C@@H](NC(=O)c1cc([N+](=O)[O-])cc([S+](=O)[O-])c1)c1ccccc1</smiles>

52 66\%, 84\% ee 
these processes. The author suggested that these metal phosphates may be generated through the purification of OC-21 on silica gel column. A dual Lewis-base activation mechanism of this desymmetrization was proposed.

\section{Chiral amino alcohols}

Lattanzi and colleagues [49] have also discovered the desymmetrization of meso- $N$-acylaziridines with benzenethiols in the presence of $\alpha, \alpha$-diaryl- $L$-prolinols (Figure 6, OC-22 to OC-25) to afford the products in good yields and moderate enantioselectivities (up to $61 \%$ ee, Scheme 7). The dual activation mode of $\alpha, \alpha$-diphenyl- $L$-prolinol (OC-23) for the desymmetrization of meso- $N$-acylaziridines is proposed in this context (Figure 7). The arylthiol was deprotonated by the pyrrolidinyl$\mathrm{N}$ of the organocatalyst to produce a highly active nucleophile, while the meso- $N$-acylaziridine was activated by the tertiaryhydroxy group of the organocatalyst by hydrogen-bonding interaction with the carbonyl-O of the acyl group in meso- $N$ acylaziridine. The latter was attacked by the highly active thio anion to furnish chiral $\beta$-amino thioethers in good yields. Interestingly, meso- $N$-tosylaziridines reacted sluggishly in both chloroform and toluene as the solvents under the same catalytic system, and the reason of this phenomenon is unknown.

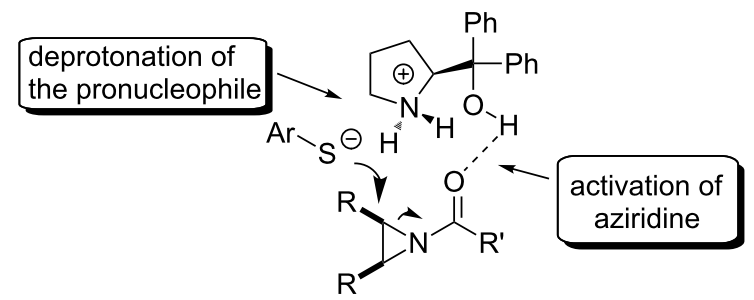

Figure 7: Proposed bifunctional mode of action of OC-23

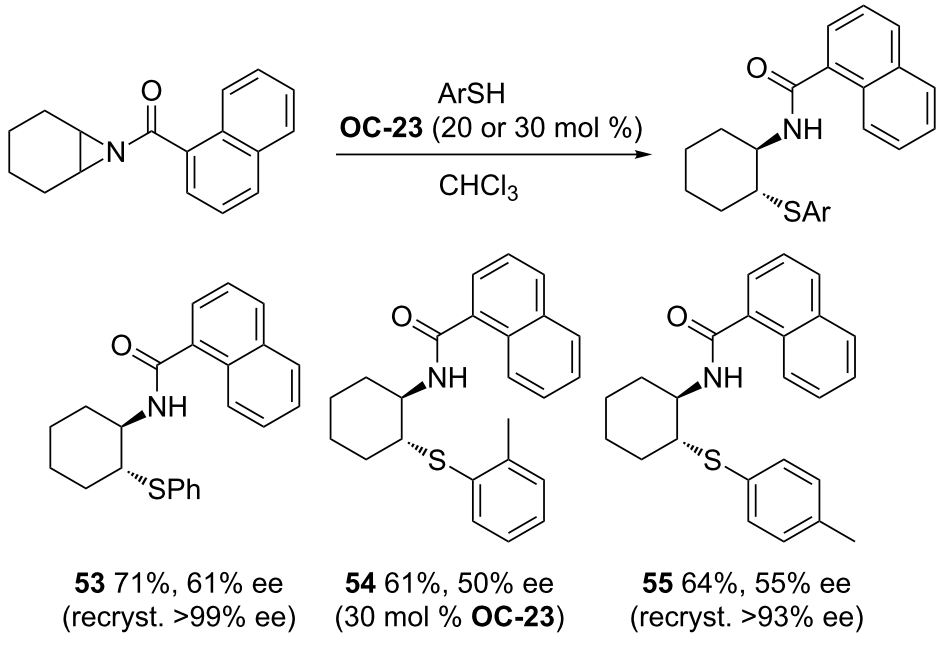<smiles>O=C(NC1CCCCC1Sc1ccc(Br)cc1)c1cccc2ccccc12</smiles>

$5682 \%, 56 \%$ ee<smiles>COc1ccc(SC2CCCCC2NC(=O)c2cccc3ccccc23)cc1</smiles>

$5779 \%, 52 \%$ ee<smiles>CC(C)(C)c1ccc(S[C@H]2CCCC[C@H]2NC(=O)c2cccc3ccccc23)cc1</smiles>

$5850 \%, 54 \%$ ee (30 mol \% OC-23)<smiles>O=C(N[C@H]1CCCC[C@H]1Sc1ccc2ccccc2c1)c1cccc2ccccc12</smiles>

$5977 \%, 37 \%$ ee 


\section{Chiral thioureas}

Jacobsen [50] and co-workers presented an enantioselective catalytic desymmetrization of meso- $\mathrm{N}$-benzoylaziridines with $\mathrm{HCl}$ by a series of chiral thioureas (Figure 8, OC-28 to OC-44). In most of the cases, a diluted reaction mixture is necessary to obtain good enantioselectivities and OC-41 proved to be the best catalyst to provide $\beta$-chlorobenzamides (Scheme 8, 60 to 66) in high yields and enantioselectivities (up to $92 \%$ ee). The ${ }^{31} \mathrm{P}$ NMR studies of the interaction between phosphinothiourea OC-41 and $\mathrm{HCl}$ indicated that the initial heterolysis of $\mathrm{HCl}$ affords a phosphonium chloride complex which is involved in the catalytic cycle. The desymmetrization of both cyclic and acyclic aziridines proceeded smoothly to give the corresponding $\beta$-chlorobenzamides in high yields and enantioselectivities.

\section{Chiral guanidines}

Tan [51] and co-workers developed a series of chiral guanidines based on an amino indanol backbone (Figure 9, OC-45 to OC-48), which proved to be very efficient organocatalysts for the enantioselective desymmetrization of meso-aziridines

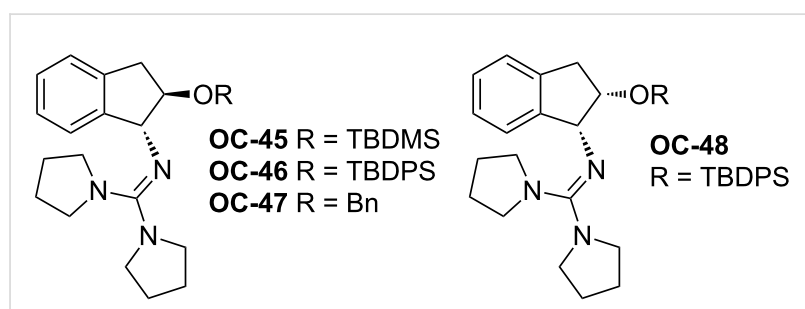

Figure 9: The chiral guanidines (OC-45 to OC-48).

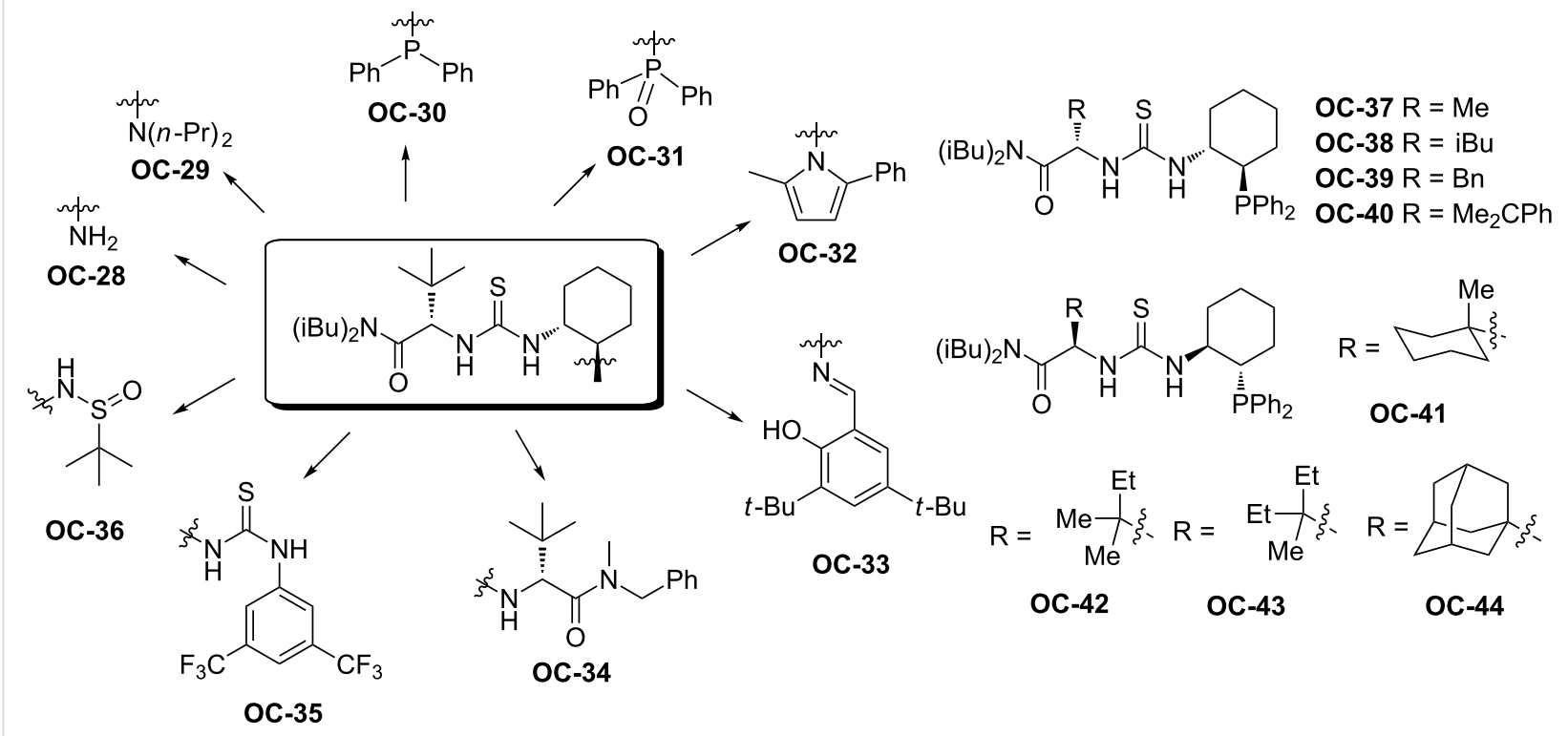

Figure 8: The chiral thioureas OC-28 to OC-44 for the desymmetrization of meso-aziridines

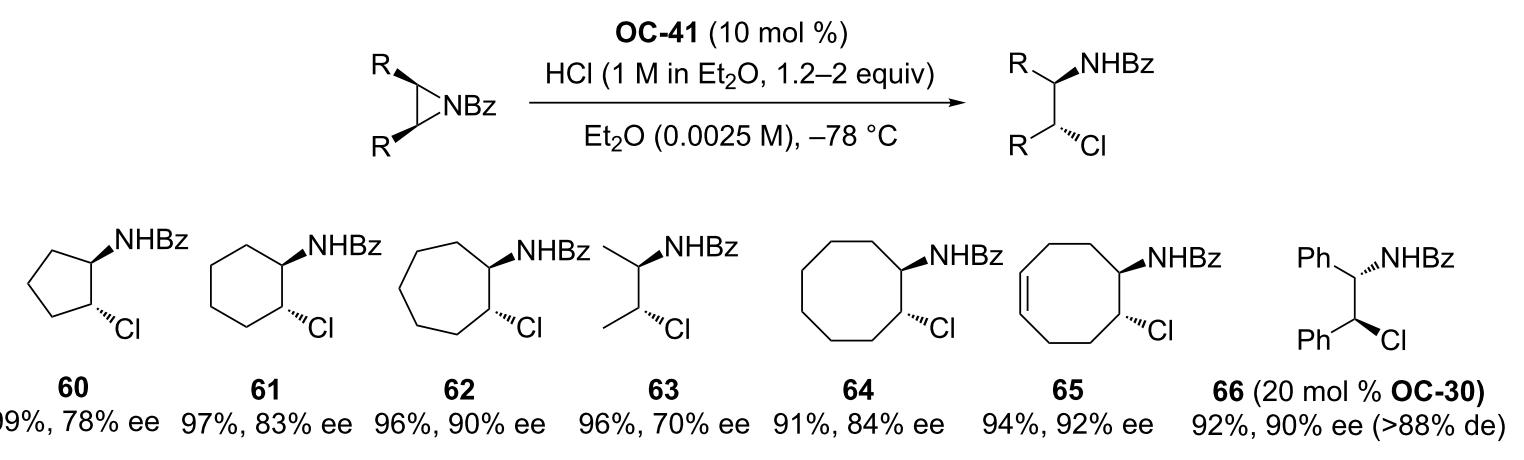

Scheme 8: Desymmetrization of meso-aziridines with OC-41. 
(Scheme 9 and Scheme 10). It was found that meso-aziridines and arylthiols containing strong electron-withdrawing groups afforded the desired products with high yields and ee's. The reaction of meso- $N$-3,5-dinitrobenzoylaziridine with 2,6-dichlorobenzenethiol provided the best enantioselectivity of the $\beta$-( $N$-acylamino)aryl thioether (up to $92 \%$ ee), with only $1 \mathrm{~mol} \%$ of chiral guanidine OC-46 as a catalyst. Based on density functional theory (DFT) calculations, a plausible mechanism indicated that the hydrogen-bonding interaction between the chiral guanidine and the carbonyl group in meso- $N$ acylaziridine is crucial for the nucleophile attack and the enantioselectivity. It seems that the increase in steric repulsion between nucleophiles and aziridines is helpful to obtain high enantioselectivities of the corresponding products (Figure 10). The desymmetrization of meso-aziridines with the in situ generation of carbamodithioic acids from amine and carbon disulfide is also investigated to provide ring-opened products $\mathbf{7 6}$ to 80 in high yields and good enantioselectivities (Scheme 11).

\section{Chiral 1,2,3-triazolium chlorides}

Most recently, Ooi [52] and colleagues have described a desymmetrization of meso- $N$-p-tert-butylphenylsulfonylaziridines

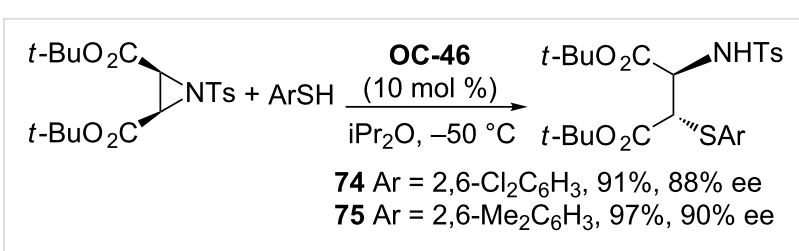

Scheme 10: Desymmetrization of cis-aziridine-2,3-dicarboxylate.

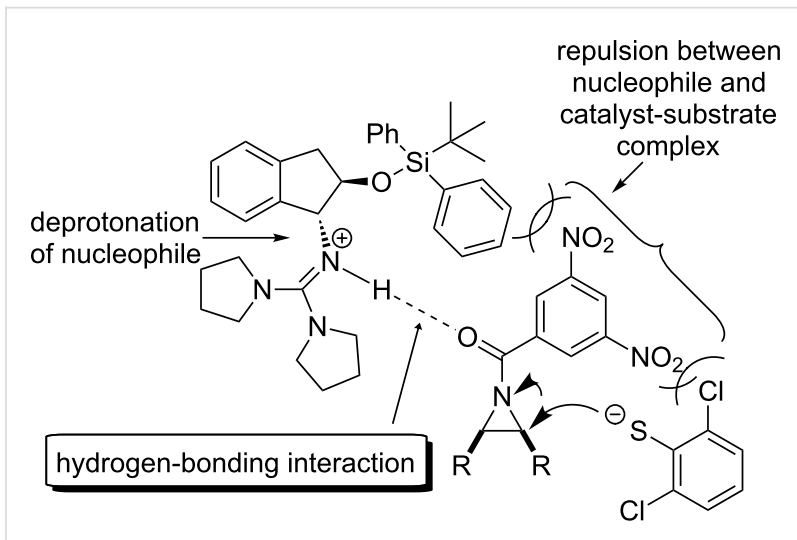

Figure 10: The proposed activation mode of OC-46.<smiles>[R]C(NC(=O)c1cc([N+](=O)[O-])cc([N+](=O)[O-])c1)C([R])Sc1c(Cl)cccc1Cl</smiles><smiles>CC(NC(=O)c1cc([N+](=O)[O-])cc([N+](=O)[O-])c1)C(C)Sc1c(Cl)cccc1[N+](=O)[O-]</smiles><smiles>O=C(N[C@H]1CCCCC[C@H]1Sc1c(Cl)cccc1Cl)c1cc([N+](=O)[O-])cc([N+](=O)[O-])c1</smiles>

$71(5 \mathrm{~mol} \%$ OC-46) $91 \%, 95 \%$ ee<smiles>O=C(N[C@H]1Cc2ccccc2C[C@H]1Sc1c(Cl)cccc1Cl)c1cc([N+](=O)[O-])cc([N+](=O)[O-])c1</smiles>

72 (5 mol \% OC-46) $90 \%, 90 \%$ ee<smiles>O=C(N[C@H](c1ccccc1)[C@H](Sc1c(Cl)cccc1Cl)c1ccccc1)c1cc([N+](=O)[O-])cc([N+](=O)[O-])c1</smiles>

73 (5 mol \% OC-46)

$93 \%, 88 \%$ ee 
<smiles></smiles><smiles>CCCCCCCC(C)OC</smiles><smiles>[R]C(NC(=O)c1cc([N+](=O)[O-])cc([N+](=O)[O-])c1)C([R])SC(=S)N(Cc1ccccc1OC)Cc1ccccc1OC</smiles><smiles>CCOC(=O)C1CCC[C@@H]1NC(=O)c1cc([N+](=O)[O-])cc([N+](=O)[O-])c1</smiles><smiles>CCOC(=O)NC(=S)S[C@H]1CCCC[C@H]1NC(=O)c1cc([N+](=O)[O-])cc([N+](=O)[O-])c1</smiles><smiles>CCOC(=O)NC(=S)SC1CC=CCC1NC(=O)c1cc([N+](=O)[O-])cc([N+](=O)[O-])c1</smiles>

$7698 \%, 91 \%$ ee $7798 \%, 96 \%$ ee<smiles>CCOC(=O)COCCOC</smiles>

$7967 \%, 90 \%$ ee<smiles>CCOC(=O)[N+](=O)[O-]</smiles>

$8091 \%, 98 \%$ ee

Scheme 11: The enantioselective desymmetrization of meso-aziridines by amine/CS 2 in the presence of OC-46.

with trimethylsilyl halides by using novel chiral 1,2,3-triazolium chlorides (OC-49 to $\mathbf{O C - 5 5}$ ) as catalysts (Figure 11). The treatment of meso-aziridine with 1 equiv of chiral 1,2,3-triazolium chloride $\mathrm{OC}-49 \cdot \mathrm{Cl}$ or $\mathrm{Me}_{3} \mathrm{SiCl}$ in toluene at $-40{ }^{\circ} \mathrm{C}$ for $12 \mathrm{~h}$ did not result in a product formation, but the combined use of a catalytic amount of $\mathbf{O C}-49 \cdot \mathrm{Cl}(5 \mathrm{~mol} \%)$ and a stoichiometric quantity of $\mathrm{Me}_{3} \mathrm{SiCl}$ led to the desired ring-opening product in low yield (35\%) and moderate enantioselectivity
(65\% ee). The control experiments indicated that the hypervalent silicate ions were involved in the reaction pathway. The enantioselectivities of the desired products were improved by modifying the substituents of catalysts and additives. It was found that the catalysts of chiral 1,2,3-triazolium chlorides containing electron-withdrawing groups usually afforded the high enantioselectivities. The more sterically hindered groups such as iPr and cyclohexyl in catalysts OC-54 and OC-55

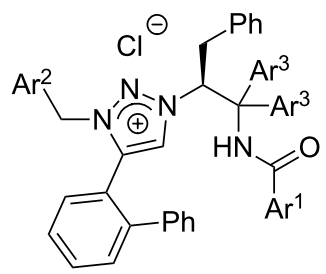

OC-49 $\mathrm{Ar}^{1}=\mathrm{Ar}^{2}=\mathrm{Ar}^{3}=\mathrm{Ph}$

OC-50 $\mathrm{Ar}^{1}=p-\mathrm{NO}_{2} \mathrm{C}_{6} \mathrm{H}_{4}, \mathrm{Ar}^{2}=\mathrm{Ar}^{3}=\mathrm{Ph}$

OC-51 Ar ${ }^{1}=p-\mathrm{NO}_{2} \mathrm{C}_{6} \mathrm{H}_{4}, \mathrm{Ar}^{2}=p-\mathrm{CF}_{3} \mathrm{C}_{6} \mathrm{H}_{4}, \mathrm{Ar}^{3}=\mathrm{Ph}$

OC-52 $\mathrm{Ar}^{1}=p-\mathrm{NO}_{2} \mathrm{C}_{6} \mathrm{H}_{4}, \mathrm{Ar}^{2}=p-\mathrm{CF}_{3} \mathrm{C}_{6} \mathrm{H}_{4}, \mathrm{Ar}^{3}=p-\mathrm{ClC}_{6} \mathrm{H}_{4}$

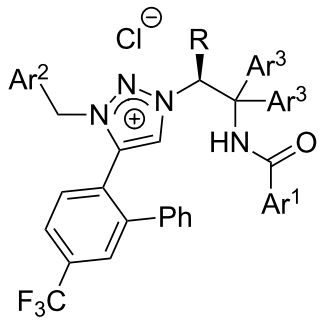

$\mathrm{Ar}^{1}=p-\mathrm{NO}_{2} \mathrm{C}_{6} \mathrm{H}_{4}, \mathrm{Ar}^{2}=p-\mathrm{CF}_{3} \mathrm{C}_{6} \mathrm{H}_{4}, \mathrm{Ar}^{3}=p-\mathrm{ClC}_{6} \mathrm{H}_{4}$

OC-53 R $=\mathrm{CH}_{2} \mathrm{Ph}$

OC-54 R $=\mathrm{CH}_{2} \mathrm{iPr}$

OC-55 R $=\mathrm{CH}_{2} \mathrm{C}-\mathrm{Hex}$ 
demonstrated better enantioselective inductions than the phenyl in OC-53. By using $10 \mathrm{~mol} \%$ of $\mathrm{Me}_{3} \mathrm{SiOH}$ as additive, both high yields (up to $99 \%$ ) and enantioselectivities (up to $95 \%$ ee) of the corresponding $\beta$-chloro- $N$-arylsulfonylamines 81 to 87 were obtained (Scheme 12). The additive in the desymmetrization was proposed to facilitate the regeneration of the active chiral triazolium chlorosilicate.

\section{Organocatalyzed enantioselective desym- metrization of meso-epoxides}

Compared to aziridines, the epoxides are much more active in their transformations because of the stronger electronegativity of the oxygen atom compared to the nitrogen atom. Some mesoepoxides are attacked by various nucleophiles to afford $\beta$-functionalized alcohols in the absence of a catalysts [53-60], so the stereo-controlling of the ring-opening of epoxides is quite challenging, and the background reaction should be suppressed to achieve high enantioselectivities. However, the catalytic asymmetric ring-opening of meso-epoxides gained much attention by its unique advantages of good atom-economy and versatile transformations. On the one hand, the desymmetrization of meso-epoxides has been successfully performed with various nucleophiles in the presence of metal-based chiral Lewis acid catalysts [61-72]. In recent years, expensive and toxic metals were more and more replaced by cheap and environmentally benign elements [73-77] such as $\mathrm{Mg}, \mathrm{Fe}, \mathrm{Ti}, \mathrm{Sc}$ and $\mathrm{Ni}$. On the other hand, the enantioselective desymmetrization of mesoepoxides by organocatalysts received much less attention, and only a few examples provided the desired products in both high yields and high enantioselectivities. In the presence of some achiral phase-transfer catalysts or phosphines such as TBAB and $\mathrm{P}(t-\mathrm{Bu})_{3}$, the vicinal chlorohydrins were obtained in high yields. Up to now, three classes of organocatalysts including chiral phosphoramides, chiral phosphine oxides, and chiral pyridine $\mathrm{N}$-oxides were used in the enantioselective desymmetrization of meso-epoxides.

\section{Organocatalyzed enantioselective ring-opening of epoxides in early stage}

In 1981, Andrews [78] and co-workers have found that the ringopening of cyclohexene and cyclopentene oxides with silicon halides was facilitated by the addition of catalytic amounts of tetra- $n$-butylammonium chloride or triphenylphosphine to afford trans $O$-protected vicinal chlorohydrins in quantitative yields. This pioneering work opened the possibility for desymmetrization of meso-epoxides by small organic molecules, but the exploration of organocatalysts for the asymmetric ringopening of epoxides remained stagnant for sixteen years.

In 1997, Fu [79] and colleagues have developed a phosphaferrocene OC-56 for the organocatalytic ring-opening of epoxides with trimethylsilyl chloride (TMSCl) to provide trans $O$-TMS protected vicinal chlorohydrins in quantitative yields under very mild conditions (Figure 12).

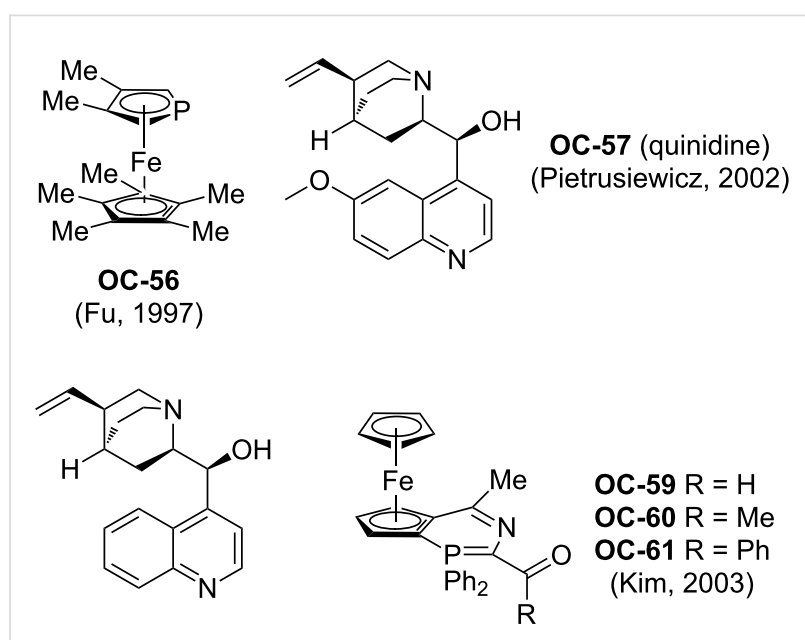

OC-58 (cinchonine)

Figure 12: Early organocatalysts for enantioselective desymmetrization of meso-epoxides.

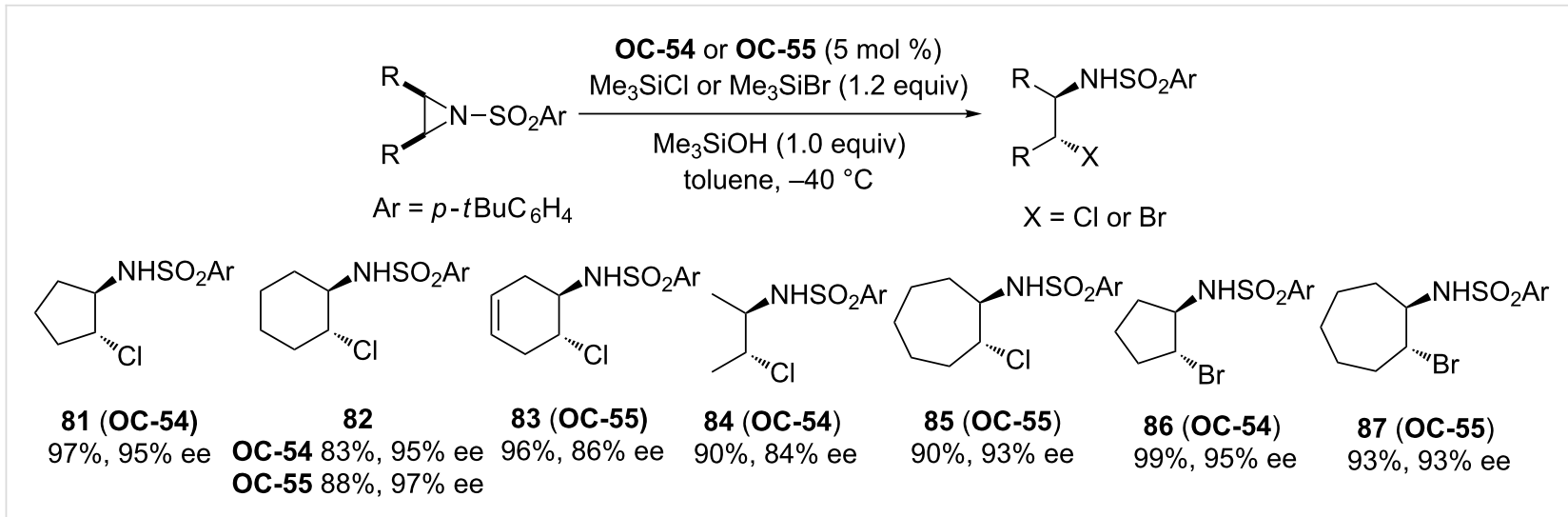

Scheme 12: The enantioselective desymmetrization of meso-aziridines by $\mathrm{Me}_{3} \mathrm{SiX}(\mathrm{X}=\mathrm{Cl}$ or $\mathrm{Br})$ in the presence of OC-54 or OC-55. 
In 2003, Kim [80] and co-workers have prepared a new class of 1,2-ferrocenediylazaphosphinines (OC-59 to OC-61), which served as organocatalysts for the ring-opening of a series of meso-epoxides to produce chlorohydrins with high yields and good regioselectivities. However, in the presence of enantiopure 1,2-ferrocenediylazaphosphinines OC-59, the desired chlorohydrins were obtained from corresponding meso-epoxides in excellent yields but with quite disappointing enantiomeric excesses (Scheme 13).

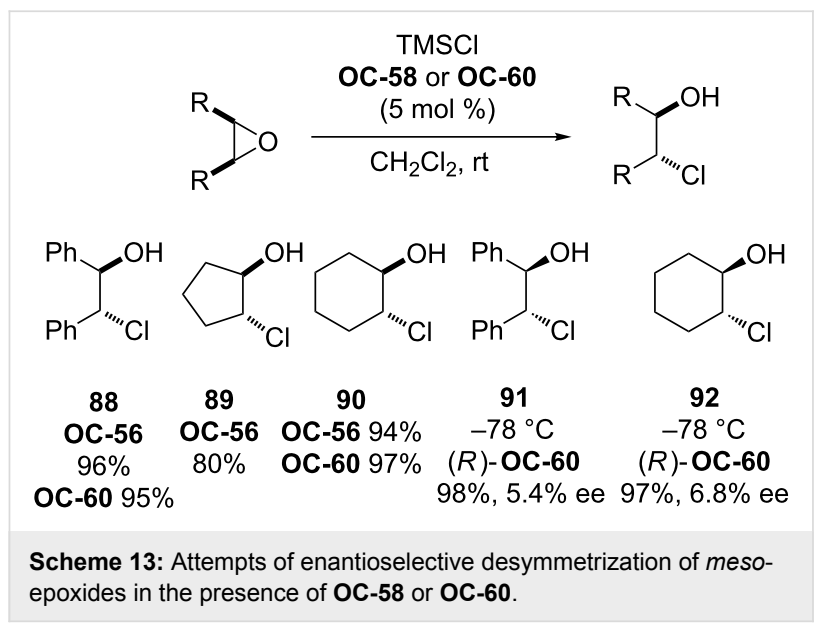

Pietrusiewicz [81] and researchers have discovered the enantioselective desymmetrization of a phospholene meso-epoxide by cinchona alkaloids to $P, C$-chirogenic 3-hydroxy-2-phospholene derivatives 93 and 94 . Among the four main components of cinchona alkaloids, quinidine (OC-57) proved to be the most effective base in the enantioselective rearrangement of epoxide, and in the presence of 0.5 equiv of quinidine, the corresponding rearranged product 94 was obtained in $41 \%$ yield with $52 \%$ ee. The other $P, C$-chirogenic phospholene derivative 93 was produced by using $100 \mathrm{~mol} \%$ cinchonidine as a promoter (Scheme 14). But this desymmetrization process is extremely sluggish and the reaction time is up to 90 days!

\section{Chiral phosphoramides and phosphine oxides}

The first efficient organocatalyzed enantioselective desymmetrization of meso-epoxides was realized by Denmark [82] and colleagues in 1998 (Figure 13). In their initial experiments, various epoxides were attacked with 1.1 equiv of freshly distilled $\mathrm{SiCl}_{4}$ by using $10 \mathrm{~mol} \%$ of HMPA as a catalyst in $\mathrm{CH}_{2} \mathrm{Cl}_{2}$ at $-78{ }^{\circ} \mathrm{C}$ to afford the corresponding trans-vicinal halohydrins in high yields (up to 96\%). This exciting discovery provides an opportunity to enantioselectively desymmetrize meso-epoxides by chiral phosphoramides. A series of chiral phosphoramides were tested. Among these organocatalysts, the chiral HMPA analogue OC-62 is most efficient to produce enantiomeric chlorohydrins in good to excellent yields but low

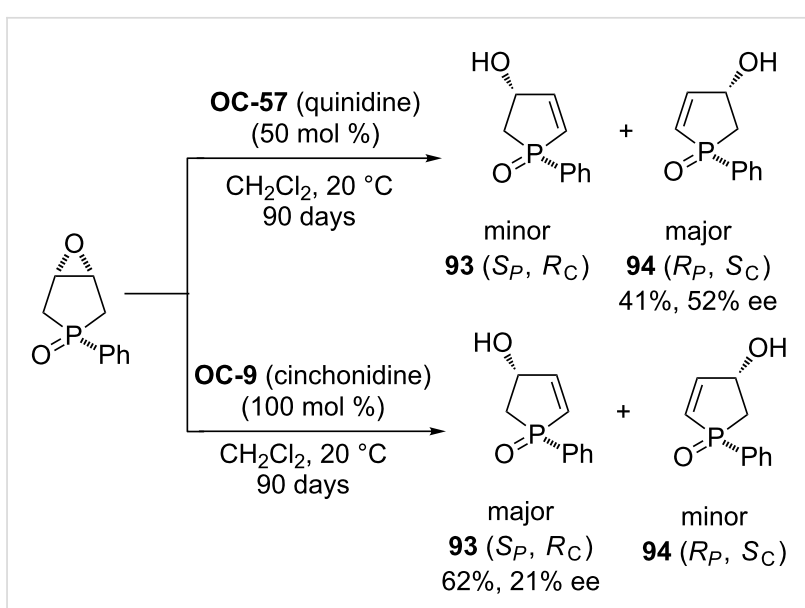

Scheme 14: The enantioselective desymmetrization of a mesoepoxide containing one $P$ atom.<smiles>[R12]P(=O)(O)c1ccc2ccccc2c1-c1c(C(=O)CC)ccc2ccccc12</smiles>

OC-62 (Denmark, 1998) OC-63 Ar = Ph (Nakajima, 2005)

OC-64 $\mathrm{Ar}=4-\mathrm{CH}_{3} \mathrm{C}_{6} \mathrm{H}_{4}$ (Benaglia, 2008)<smiles>O=P(P)(c1ccccc1)c1ccc2c(c1C1=C(P(=O)(c3ccccc3)c3ccccc3)C=CC3CCCCC13)CCCC2</smiles>
OC-65 $\mathrm{Ar}=3,5-\mathrm{Me}_{2} \mathrm{C}_{6} \mathrm{H}_{3}$

OC-66<smiles>O=P(O)(c1ccccc1)c1ccc2c(c1-c1c(P(=O)(c3ccccc3)c3ccccc3)ccc3c1OCO3)OCO2</smiles>

OC-67<smiles>CC1(C)OC(C[P+](=O)Pc2ccccc2)C(CP(=O)(c2ccccc2)c2ccccc2)O1</smiles>

OC-68<smiles>Cc1sc(C)c(-c2c(C)sc(C)c2P(=O)(O)c2ccccc2)c1C(=O)O</smiles>

OC-69 (Benaglia, 2008)

Figure 13: Some chiral phosphoramide and chiral phosphine oxides.

enantioselectivities except with acyclic meso-epoxides (Scheme 15). The highest enantioselectivity was $87 \%$ ee. The proposed reaction mechanism is depicted in Figure 14. The first step of the catalytic cycle is the activation of $\mathrm{SiCl}_{4}$ by chiral phosphoramide OC-62 to form a complex, which was ionized to produce a highly reactive silicon cation and a chloride ion. The epoxide was activated by the chiral complexation of the 
phosphorus/silicon cation, and then followed by an attack with the chloride ion in an $\mathrm{S}_{\mathrm{N}} 2$ fashion to furnish chlorohydrin enantioselectively (Figure 14).

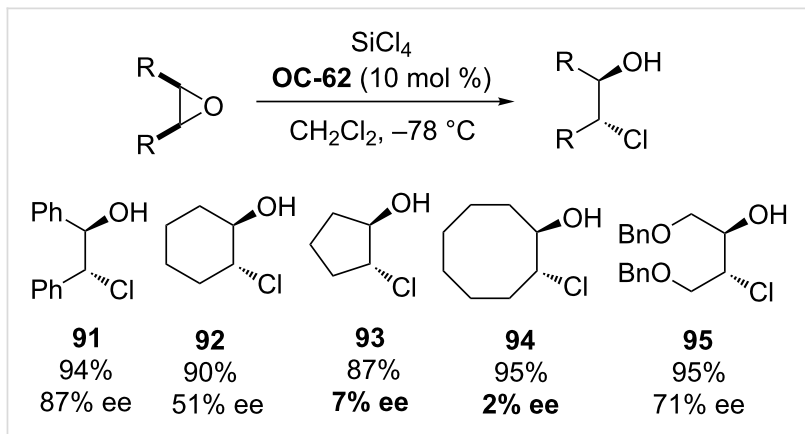

Scheme 15: OC-62 catalyzed enantioselective desymmetrization of meso-epoxides by $\mathrm{SiCl}_{4}$.

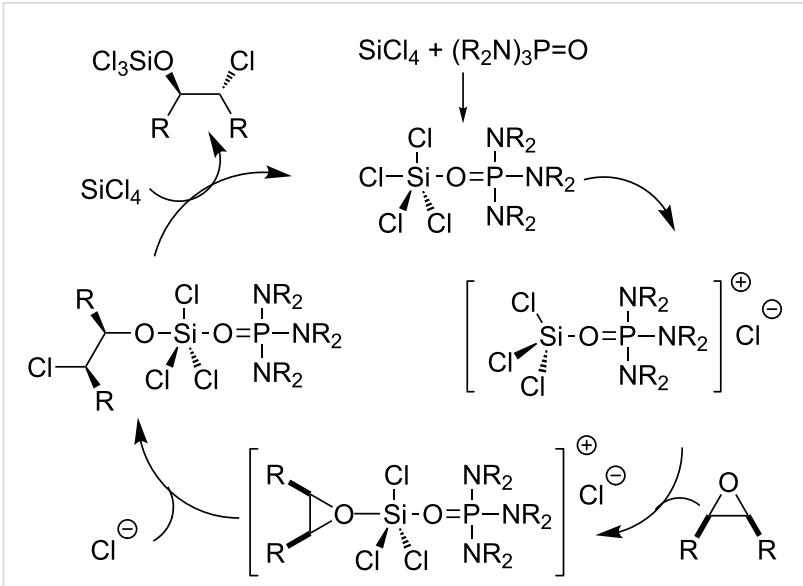

Figure 14: The proposed mechanism of the chiral HMPA-catalyzed desymmetrization of meso-epoxides.

From this description, the activation of $\mathrm{SiCl}_{4}$ was depending on the formation of the chiral complexation of the phosphorus/ silicon cation through the oxygen atom of $\mathrm{P}=\mathrm{O}$ and the coordination with the silicon atom of the nucleophiles. It can be deduced that the chiral phosphine oxides can also play a role for the activation of $\mathrm{SiCl}_{4}$ and serve as catalysts for the desymmetrization of meso-epoxides. The first example of a chiral phosphine oxide-catalyzed asymmetric ring-opening of mesoepoxides has been realized by Nakajima [83] and co-workers and proved to be very effective. They have prepared a chiral phosphine oxide BINAPO (OC-63) based on a binaphthylskeleton, which was utilized as an organocatalyst for the enantioselective desymmetrization of meso-epoxides by $\mathrm{SiCl}_{4}$. In the presence of 1.5 equiv of $\mathrm{iPr}_{2} \mathrm{NEt}$, various acyclic and cyclic meso-epoxides were desymmetrized to enantioenriched chlorohydrins (96 to 101) in high yields (Scheme 16). When mesostilbene oxide was used as a substrate, the best enantioselectivity was up to $90 \%$ ee under optimum conditions. However, the other substrates, including the meso-epoxides derived from butenediol, pyrroline and dihydrofuran, gave quite disappointing enantioselectivities. Interestingly, OC-65 significantly reduced the enantioselectivities under the optimized conditions, but the chiral phosphine oxides OC-66 and OC-67 afforded enantioselectivities similar to that of BINAPO (OC-63). This indicated that the substituents on the phenyl ring had a remarkable effect on the enantioselectivities in the desymmetrization of meso-epoxides [84]. Benaglia [85] and colleagues have developed chiral phosphine oxides OC-64 and OC-69 for the enantioselective desymmetrization of meso-stilbene oxide to provide the corresponding vicinal chlorohydrin 96 in up to $82 \%$ ee.

More recently, Ready [86] and co-workers have synthesized a series of chiral phosphine oxides (OC-70 to OC-77) based on an allene backbone (Figure 15). These novel chiral mono- and bisphosphine oxides were investigated as organocatalysts for the efficient enantioselective desymmetrization of meso-epoxides. Due to the lack of $C_{2}$ symmetry of mono-phosphine oxides, they displayed lower reactivities and enantioselectivities than the bisphosphine oxides. The variation of the substituents on the allene itself was tolerated in the desymmetrization processes, but both the yields and the enantioselectivities are sensitive to changes in the aryl rings on the phosphine oxide. It was found that the diphenyl-substituted

$$
\underset{R}{\mathrm{R}} \underset{\mathrm{CH}_{2} \mathrm{Cl}_{2}, \mathrm{iPr}_{2} \mathrm{NEt},-78^{\circ} \mathrm{C}}{\stackrel{\mathrm{SiCl}_{4}, \mathrm{OC}-63(10 \mathrm{~mol} \%)}{\mathrm{C}_{\mathrm{Cl}}}} \overbrace{\mathrm{Cl}}^{\mathrm{R}}
$$<smiles>OC(c1ccccc1)c1ccccc1</smiles><smiles>O[C@H]1CCCC[C@H]1Cl</smiles><smiles>OC1COCC1Cl</smiles><smiles>OC1CN([As])CC1Cl</smiles>

99 95\%, 34\% ee<smiles>O[C@H]1CCCCCCC1Cl</smiles><smiles>O[C@H](COCBr)C(Cl)COBr</smiles> 
catalyst $\mathbf{O C}-\mathbf{7 3}$ is a highly reactive and enantioselective catalyst to produce the chlorohydrins in up to $94 \%$ ee with only $0.1 \mathrm{~mol} \%$ catalyst-loading. The cis-stilbene oxides with substituent in the meta or para position are tolerated, the yields and enantioselectivities of desired chlorohydrins are satisfying, but ortho-substituted stilbene oxides are not reactive in the desymmetrization under the same reaction conditions. Unsatisfactorily, the desymmetrization of linear, cyclic, or bicyclic aliphatic meso-epoxides resulted in corresponding chlorohydrins in high yield but with low enantiomeric excesses (Scheme 17).

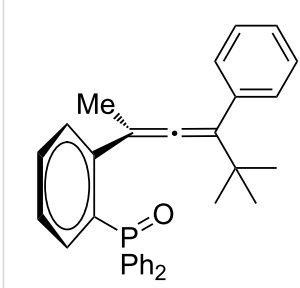

OC-70

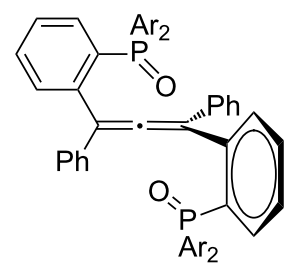

Figure 15: The Chiral phosphine oxides (OC-70 to OC-77) based on an allene backbone.

\section{Chiral pyridine $\mathrm{N}$-oxides}

The breakthrough of the organocatalyzed enantioselective desymmetrization of meso-epoxides was the employment of chiral pyridine $\mathrm{N}$-oxides as catalysts. In 2001, Fu [87] and colleagues demonstrated the utilization of selected chiral pyridine $N$-oxides in the enantioselective desymmetrization of meso-epoxides. These novel chiral pyridine $N$-oxides possess a plane of chirality in a ferrocenyl backbone. The steric hindrance of the $\mathrm{Fe}\left(\eta^{5}-\mathrm{C}_{5} \mathrm{Ar}_{5}\right)$ group on catalysts (Figure 16, OC-78 to OC-80) is very crucial to the enantioselectivities of desym-

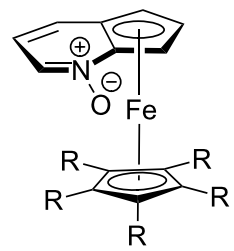

OC-78 $\mathrm{R}=\mathrm{Me}$

OC-79 $\mathrm{R}=\mathrm{Ph}$

OC-80 R = 3,5-(Me $)_{2} \mathrm{C}_{6} \mathrm{H}_{3}$<smiles></smiles>

OC-82<smiles>Cc1ccc2ccccc2c1-c1c2ccccc2cc[n+]1[O-]</smiles>

OC-83

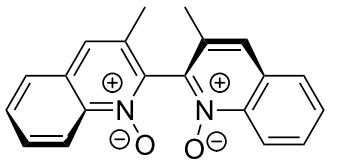

OC-81

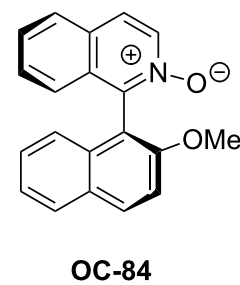

Figure 16: Chiral pyridine $\mathrm{N}$-oxides used in enantioselective desymmetrization of meso-epoxides.

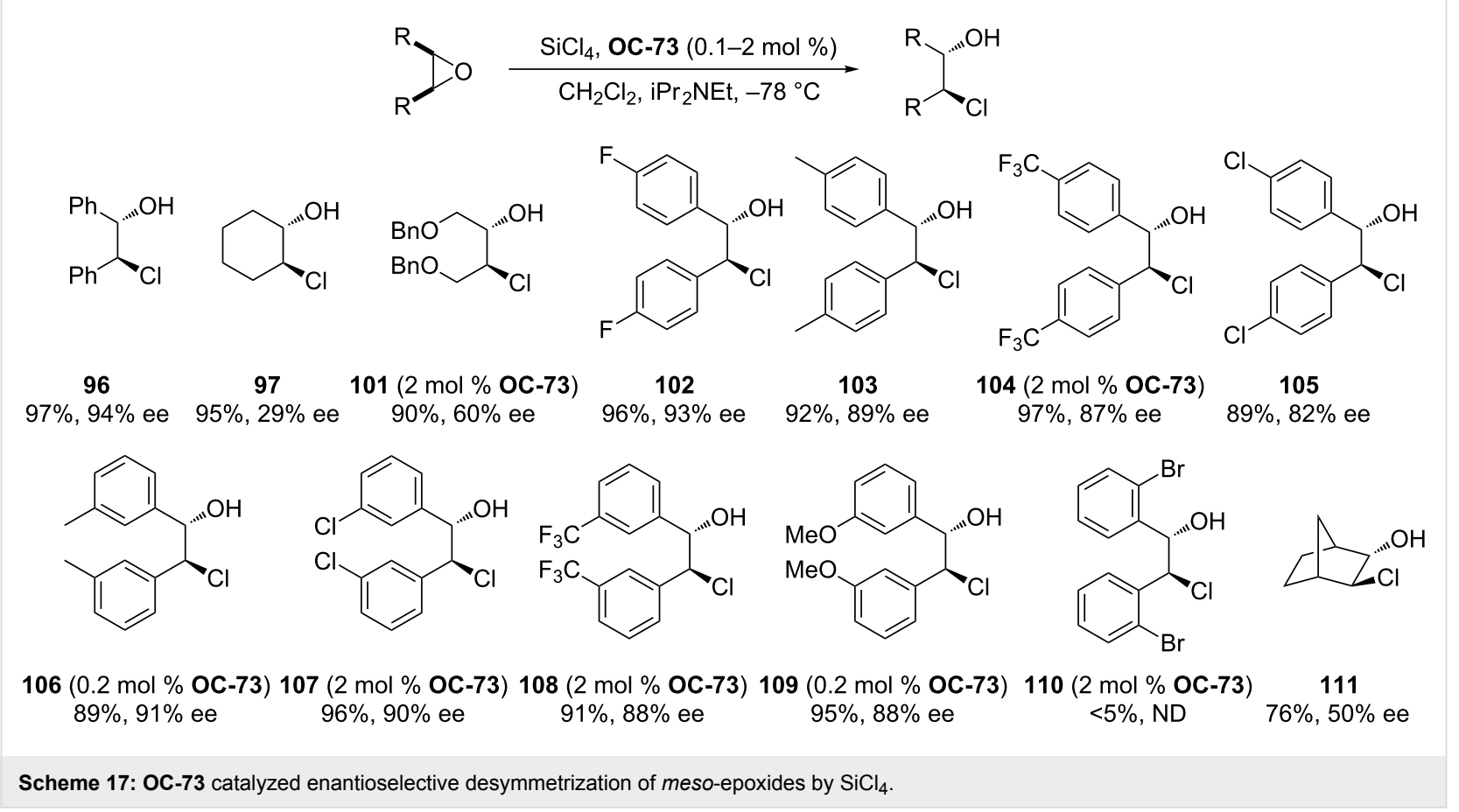


metrization of meso-epoxides. The increase of steric hindrance of the $\mathrm{Fe}\left(\eta^{5}-\mathrm{C}_{5} \mathrm{Ar}_{5}\right)$ group can indeed lead to increased enantioselectivities of the desired chlorohydrins. For example, by shifting the substituents on $\mathrm{Fe}\left(\eta^{5}-\mathrm{C}_{5} \mathrm{Ar}_{5}\right)$ from phenyl (OC-79) to 3,5-dimethylphenyl (OC-80), the enantioselectivity of desymmetrization of cis-stilbene oxide with $\mathrm{SiCl}_{4}$ at roomtemperature was improved significantly from 25 to $68 \%$ ee. The highest enantiomeric excess of chlorohydrin $(92 \%$ ee) was obtained by simple decreasing the reaction temperature to $-78{ }^{\circ} \mathrm{C}$. A series of substituted cis-stilbene oxides were desymmetrized in very good yield and high stereoselection, and the substrates with electron-withdrawing group such as $\mathrm{F}$ or $\mathrm{CF}_{3}$ at the aryl ring can produce chlorohydrins with excellent enantioselectivities (up to $98 \%$ ee). Further investigation indicated that the catalyst-loading can be decreased to be $1 \mathrm{~mol} \%$ and $\mathbf{O C}-\mathbf{8 0}$ can be recovered nearly quantitatively $(>90 \%)$ with high ee's.

After Fu's work, two axially-chiral bipyridine $N, N^{\prime}$-dioxides OC-81 and OC-82 were selected by Nakajima [88] and co-workers for the enantioselective desymmetrization of mesoepoxides (Scheme 18). When $\mathrm{SiCl}_{4}$ was used as a nucleophile, the desymmetrization of $c i s$-stilbene oxide was performed smoothly in the presence of $10 \mathrm{~mol} \%$ of catalyst $\mathbf{O C - 8 1}$ in dichloromethane at $-78{ }^{\circ} \mathrm{C}$ with $\mathrm{iPr}_{2} \mathrm{NEt}$ as a base to give chlorohydrin in $94 \%$ yield and $56 \%$ ee. The ee of chlorohydrin was increased to $90 \%$ by using $\mathbf{O C - 8 2}$ as a catalyst under the same conditions, but the use of methyl-, allyl-, or phenyltrichlorosilane as a nucleophile gave racemic products. The choice of a proper solvent is very crucial to the stereoselection. For example, THF or toluene as a solvent gave the chlorohydrin in almost racemic form. The substituted cis-stilbene oxides can provide the corresponding chlorohydrins in high chemical yields and ee's, but meso-cyclohexene oxide resulted in a racemic product under the optimal conditions. Because of the low catalytic activities of axially-chiral pyridine $\mathrm{N}$-oxides OC-83 or OC-84 in the desymmetrization process, a hexacoordinate silicate intermediate between $\mathrm{SiCl}_{4}$ and chiral bipyridine $N, N^{\prime}$-dioxide $\mathbf{O C - 8 2}$ was envisaged to explain the good enantioselectivity of catalyst $\mathbf{O C}-\mathbf{8 2}$.

In 2008, a set of enantiomerically pure $C_{2}$-symmetric bipyridine mono- $N$-oxides and $N, N^{\prime}$-dioxides (OC-85 to OC-94) derived from naturally occurring monoterpenes have been synthesized by Benaglia [89] and colleagues (Figure 17). These chiral bipyridine $N, N^{\prime}$-dioxides were utilized in the enantioselective desymmetrization of $c i s$-stilbene oxide and cyclooctene epoxide with $\mathrm{SiCl}_{4}$. Some showed high catalytic activities but with low to moderate enantioselectivities. Among them, chiral bipyridine $N, N$ '-dioxide $\mathbf{O C - 8 7}$ proved to be the most efficient to produce the corresponding chlorohydrins in quantitative yields and good enantioselectivities (up to $70 \%$ ee). Unfortu-

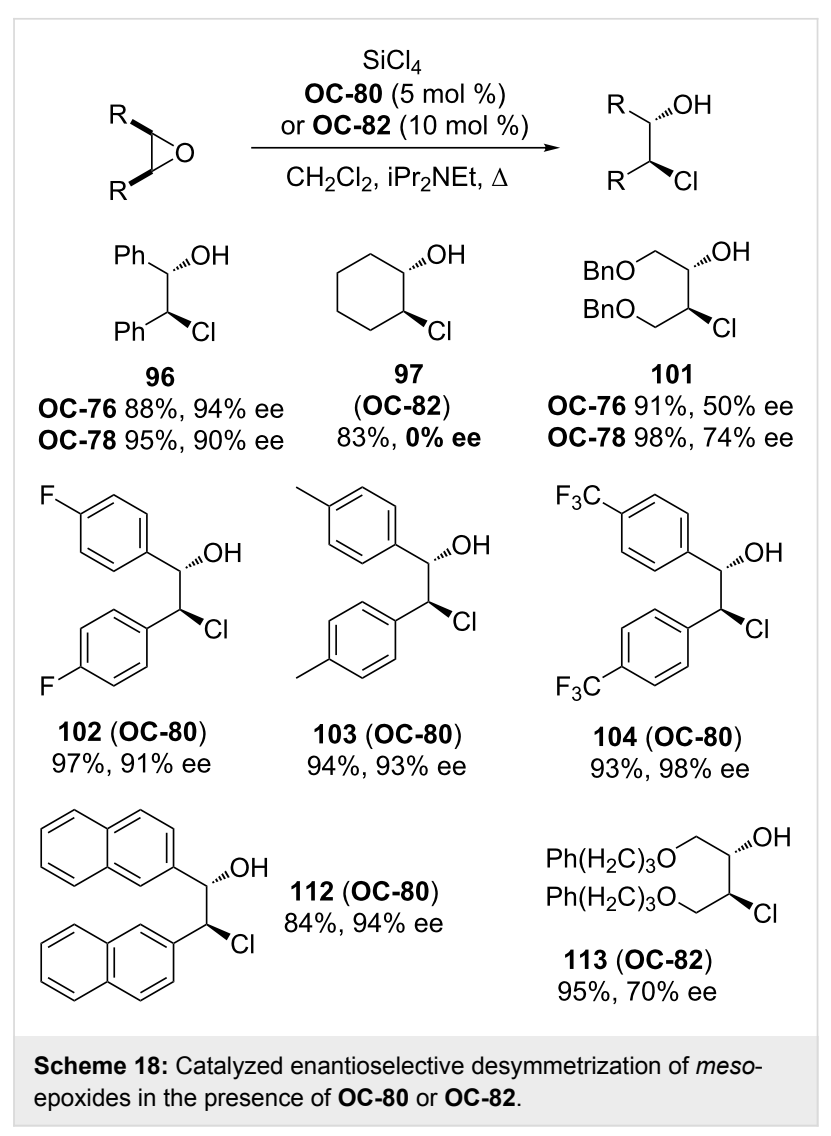

nately, chiral bipyridine mono- $N$-oxides OC-89 and OC-90 provided racemic chlorohydrins (Scheme 19).

Takenaka's group [90] has developed a novel family of helical chiral pyridine $N$-oxides (Figure 18, OC-95 to OC-97) which were employed as catalysts for the enantioselective desymmetrization of meso-epoxides with $\mathrm{SiCl}_{4}$. All catalysts demonstrated high activities in the desymmetrization process but with different enantioselectivities. The substrates containing aromatic substituents can provide the corresponding chlorohydrins in higher enantioselectivities than those bearing alkyl groups. Unfortunately, the cyclic epoxides produced the chlorohydrins 115 and 117 in low ee's (Scheme 20).

Kočovský [91] and colleagues have introduced a chiral bipyridine mono- $N$-oxide PINDOX OC-98 for the enantioselective ring-opening of cyclic meso-epoxides with $\mathrm{SiCl}_{4}$ to produce chlorohydrins in moderate to good enantiomeric excess (Scheme 21). The stereoselectivities are very sensitive to the ring size of the cyclic oxides. For example, when cyclohexene oxide was used as a substrate, the corresponding chlorohydrin was obtained in nearly racemic form. The greater the ring sizes of the cyclic oxides, the higher the enantioselectivities. It was found that the catalyst OC-98 is unique for the desymmetrization of meso-cyclooctene oxide, which was proved to be a 


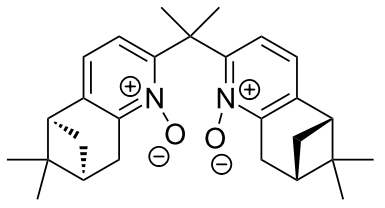

OC-85

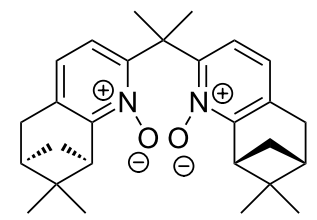

OC-88<smiles>C[C@@H]1C=[N+]([O-])C2=CC=C1[C@@H](C)[C@H]1C[C@H]3Cc4c(ccc([n+]4[O-])C2(C)C)C1C3(C)C</smiles>

OC-86<smiles></smiles>

OC-89

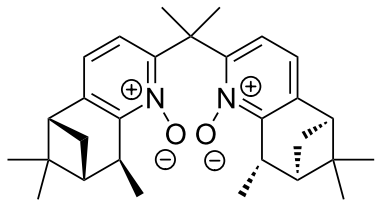

OC-87<smiles></smiles>

OC-90

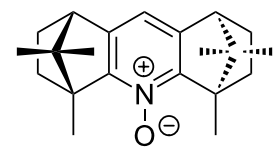

OC-91

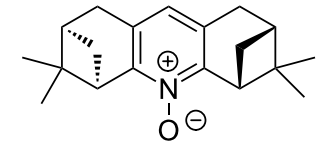

OC-92<smiles>CC1c2c(cc3c([n+]2[O-])[C@H](C)[C@H]2C[C@H]3C2(C)C)C1C(C)(C)C</smiles>

OC-93<smiles>CO[C@H]1c2c(ccc(-c3ccccc3)[n+]2[O-])[C@H]2C[C@H]1C2(C)C</smiles>

OC-94

Figure 17: Chiral pyridine $\mathrm{N}$-oxides OC-85 to OC-94.

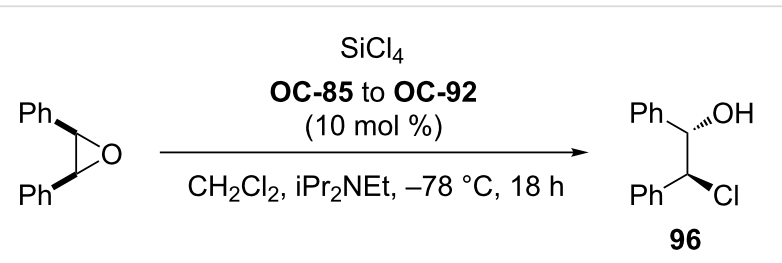

OC-85 100\%, <5\% ee; OC-86 71\%, 7\% ee;

OC-87 100\%, 70\% ee; OC-88 91\%, 38\% ee;

OC-89 50\%, <5\% ee; OC-90 47\%, <5\% ee;

OC-91 77\%, 5\% ee; OC-92 83\%, 37\% ee

Scheme 19: Enantioselective desymmetrization of cis-stilbene oxide by using $O C-85$ to $O C-92$ as catalysts.

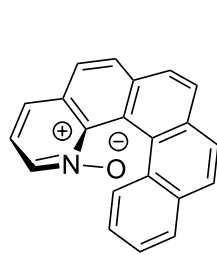

OC-95

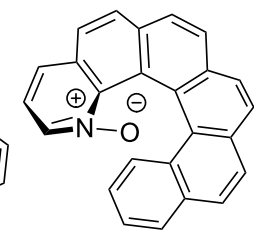

OC-96

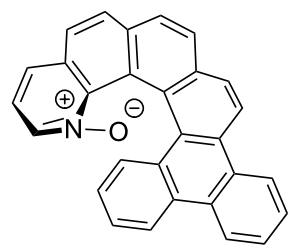

OC-97
Figure 18: A novel family of helical chiral pyridine $\mathrm{N}$-oxides $\mathrm{OC}-95$ to OC-97.

very challenging substrate for desymmetrization with other reported organocatalysts, and the chlorohydrin 94 was obtained in $90 \%$ ee in the presence of $10 \mathrm{~mol} \%$ of OC-98 in dichloro- methane at $-90{ }^{\circ} \mathrm{C}$. Interestingly, the tricyclic exo-norbornene oxide afforded the syn-exo-chloroalcohol $\mathbf{1 2 3}$ as the major product in 53\% yield and $90 \%$ ee by a Wagner-Meerwein rearrangement. The mechanism of the enantioselective desymmetrization of meso-epoxides by chiral pyridine $N$-oxides is not fully understood at the time of this writing.

\section{Conclusion}

In this review, we summarized the recent advances of the organocatalyzed enantioselective desymmetrization of mesoaziridines and meso-epoxides. Undoubtedly, these synthetic methodologies will continue to demonstrate their versatile utilities in organic synthesis. However, there are some difficulties that should be pointed out.

Organocatalysts for the enantioselective desymmetrization of meso-aziridines are plentiful and can be found in a diverse set of privileged structures, including cinchona alkaloids-based PTCs, $L$-proline-derived amino alcohols, chiral phosphorous acids, chiral thioureas, chiral guanidines, and chiral 1,2,3-triazolium chlorides. But for the desymmetrization of meso-epoxides efficient catalysts are presently limited to chiral phosphine oxides and chiral pyridine $N$-oxides. Obviously, there is still a need for the exploration of more efficient organocatalysts with high enantioselectivities in this field. In most cases, the catalystloading is up to $10 \mathrm{~mol} \%$, and some catalysts are not readily accessible and tunable. Therefore, the search for practical 


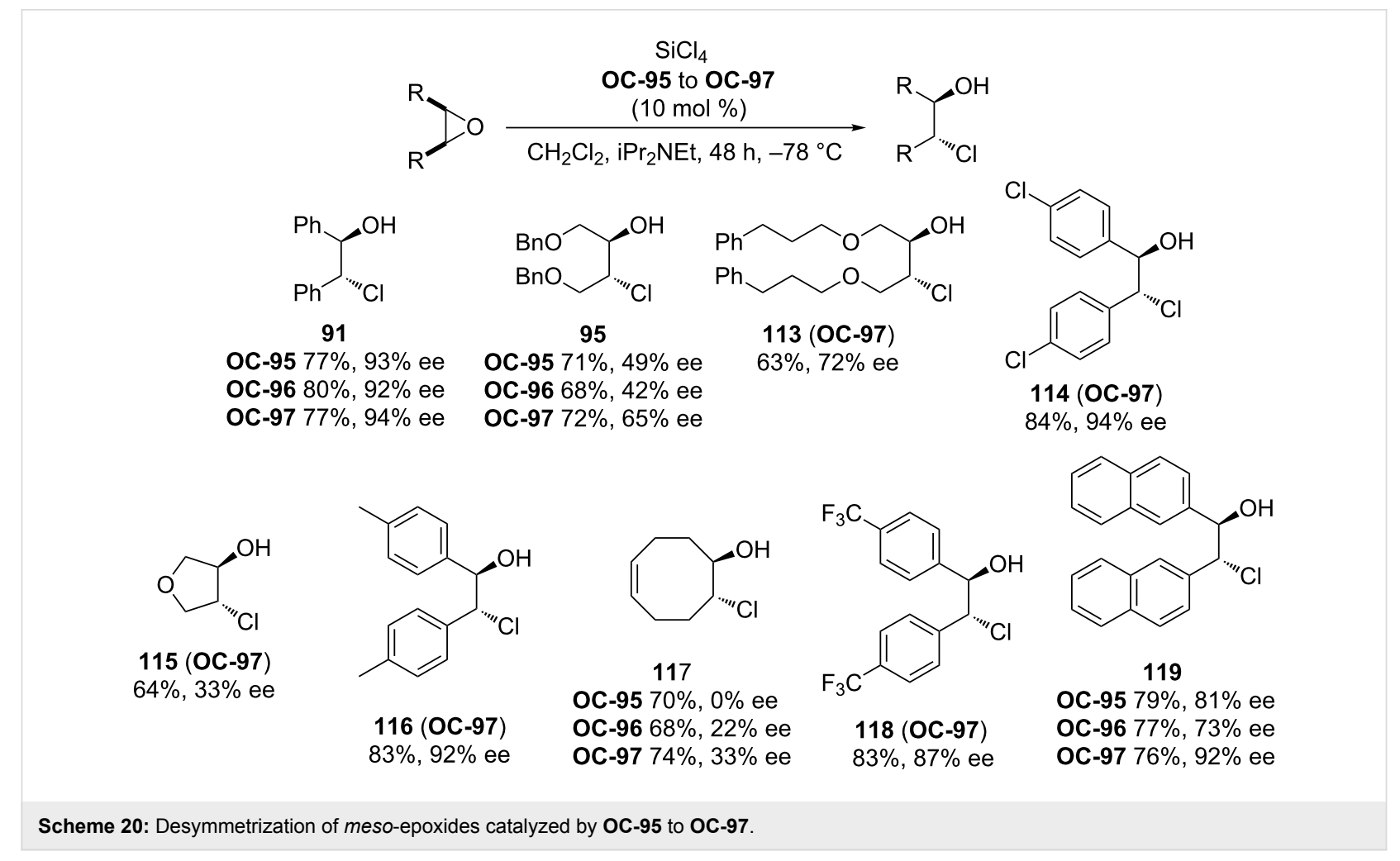

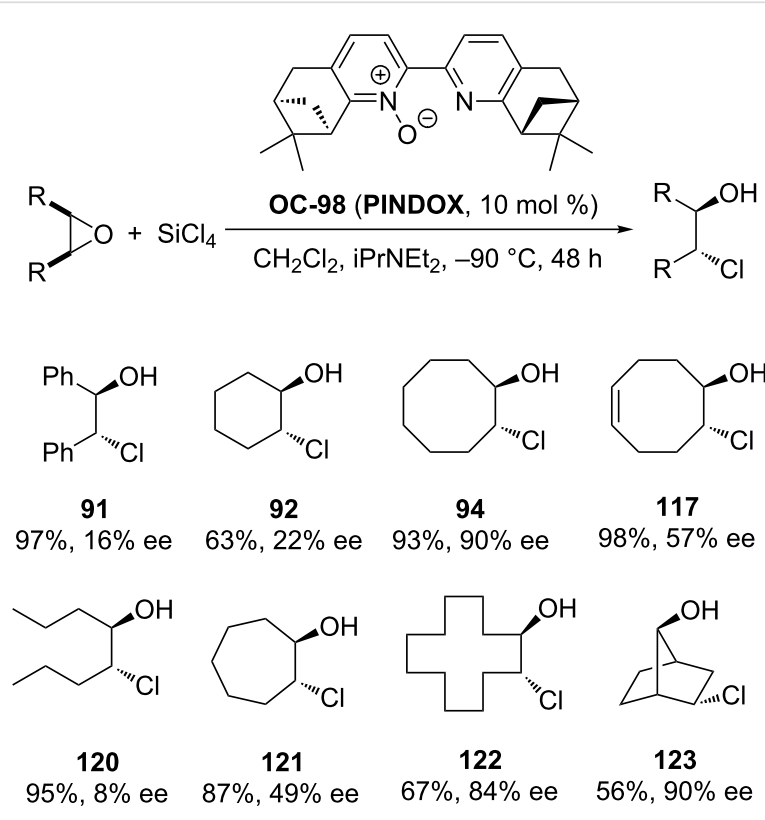

Scheme 21: OC-98 catalyzed enantioselective desymmetrization of meso-epoxides by $\mathrm{SiCl}_{4}$.

methods for the facile synthesis of organocatalysts, which exhibit a plethora of applications, is still in high demand.

Various C-, N-, S-, Se- and halo-nucleophiles are involved in the organocatalyzed enantioselective desymmetrization of meso-aziridines to afford $\beta$-functional amine derivatives with high yields and enantioselectivities, while the organocatalyzed enantioselective desymmetrization of meso-epoxides is restricted to chloro-nucleophiles. More specifically, $\mathrm{SiCl}_{4}$ was used in most cases to produce enantioenriched chlorohydrins. It might be worthwhile to extend research activities toward nucleophiles which are able to produce chiral $\beta$-functional alcohols.

The acyclic meso-aziridines and meso-epoxides usually showed disappointing results except for a few examples. With some further mechanism studies, new and more efficient organocatalysts for the enantioselective desymmetrization of mesoaziridines and meso-epoxides with a broader substrate scope and milder reaction conditions may be discovered [92-95].

\section{Acknowledgements}

P. A. Wang thanks Prof. Henri B. Kagan for his instructive discussion of this review.

\section{References}

1. Ojima, I. Catalytic Asymmetric Synthesis, 3rd ed.; Wiley-VCH: Weinheim, Germany, 2010.

2. Bates, R. Organic Synthesis Using Transition Metals, 2nd ed.; John Wiley \& Sons: West Sussex, U.K., 2012.

3. Crawley, M. L.; Trost, B. M., Eds. Applications of Transition Metal Catalysis in Drug Discovery and Development: An Industrial Perspective; John Wiley \& Sons: Hoboken, NJ, U.S.A., 2012. 
4. Enríquez-García, Á.; Kündig, E. P. Chem. Soc. Rev. 2012, 41, 7803-7831. doi:10.1039/C2CS35049A

5. Díaz-de-Villegas, M. D.; Gálvez, J. A.; Badorrey, R.; López-Ram-de-Víu, M. P. Chem.-Eur. J. 2012, 18, 13920-13935. doi:10.1002/chem.201202264

6. Willis, M. C. J. Chem. Soc., Perkin Trans. 1 1999, 1765-1784. doi:10.1039/A906269B

7. Giacalone, F.; Gruttadauria, M.; Agrigento, P.; Noto, R. Chem. Soc. Rev. 2012, 41, 2406-2447. doi:10.1039/C1CS15206H

8. Renzi, P.; Bella, M. Chem. Commun. 2012, 48, 6881-6896. doi:10.1039/C2CC31599H

9. Dondoni, A.; Massi, A. Angew. Chem., Int. Ed. 2008, 47, 4638-4660. doi:10.1002/anie.200704684

10. Hu, X. E. Tetrahedron 2004, 60, 2701-2743. doi:10.1016/j.tet.2004.01.042

11. Lu, P. Tetrahedron 2010, 66, 2549-2560. doi:10.1016/j.tet.2010.01.077

12. Stanković, S.; D'hooghe, M.; Catak, S.; Eum, H.; Waroquier, M.; Van Speybroeck, V.; De Kimpe, N.; Ha, H.-J. Chem. Soc. Rev. 2012, 41, 643-665. doi:10.1039/C1CS15140A

13. Pastor, I. M.; Yus, M. Curr. Org. Chem. 2005, 9, 1-29. doi:10.2174/1385272053369385

14. Dhakshinamoorthy, A.; Alvaro, M.; Concepción, P.; Fornés, V.; Garcia, H. Chem. Commun. 2012, 48, 5443-5445. doi:10.1039/C2CC31385E

15. Bonollo, S.; Lanari, D.; Vaccaro, L. Eur. J. Org. Chem. 2011, 2587-2598. doi:10.1002/ejoc.201001693

16. Nakamura, S.; Hayashi, M.; Kamada, Y.; Sasaki, R.; Hiramatsu, Y.; Shibata, N.; Toru, T. Tetrahedron Lett. 2010, 51, 3820-3823. doi:10.1016/j.tetlet.2010.05.065

17. Arai, K.; Lucarini, S.; Salter, M. M.; Ohta, K.; Yamashita, Y.; Kobayashi, S. J. Am. Chem. Soc. 2007, 129, 8103-8111. doi:10.1021/ja0708666

18. Fukuta, Y.; Mita, T.; Fukuda, N.; Kanai, M.; Shibasaki, M. J. Am. Chem. Soc. 2006, 128, 6312-6313. doi:10.1021/ja061696k

19. Wu, B.; Gallucci, J. C.; Parquette, J. R.; RajanBabu, T. V. Angew. Chem., Int. Ed. 2009, 48, 1126-1129. doi:10.1002/anie.200804415

20. Fujimori, I.; Mita, T.; Maki, K.; Shiro, M.; Sato, A.; Furusho, S.; Kanai, M.; Shibasaki, M. J. Am. Chem. Soc. 2006, 128, 16438-16439. doi:10.1021/ja067003h

21. Schaus, S. E.; Brandes, B. D.; Larrow, J. F.; Tokunaga, M.; Hansen, K. B.; Gould, A. E.; Furrow, M. E.; Jacobsen, E. N. J. Am. Chem. Soc. 2002, 124, 1307-1315. doi:10.1021/ja016737।

22. Schneider, C.; Sreekanth, A. R.; Mai, E. Angew. Chem., Int. Ed. 2004, 43, 5691-5694. doi:10.1002/anie.200460786

23. Li, Z.; Fernández, M.; Jacobsen, E. N. Org. Lett. 1999, 1, 1611-1613. doi:10.1021/ol990992h

24. Schneider, C. Angew. Chem., Int. Ed. 2009, 48, 2082-2084. doi:10.1002/anie.200805542

25. Xu, Y.; Lin, L.; Kanai, M.; Matsunaga, S.; Shibasaki, M. J. Am. Chem. Soc. 2011, 133, 5791-5793. doi:10.1021/ja201492x

26. Peruncheralathan, S.; Henze, M.; Schneider, C. Tetrahedron Lett. 2007, 48, 6743-6746. doi:10.1016/j.tetlet.2007.07.082

27. Kalow, J. A.; Doyle, A. G. J. Am. Chem. Soc. 2010, 132, 3268-3269. doi:10.1021/ja100161d

28. Peruncheralathan, S.; Aurich, S.; Teller, H.; Schneider, C. Org. Biomol. Chem. 2013, 11, 2787-2803. doi:10.1039/С3ОB40222C

29. Blyumin, E. V.; Gallon, H. J.; Yudin, A. K. Org. Lett. 2007, 9 , 4677-4680. doi:10.1021/ol7015302
30. Minakata, S.; Okada, Y.; Oderaotoshi, Y.; Komatsu, M. Org. Lett. 2005 , 7, 3509-3512. doi:10.1021/ol051186f

31. Fan, R.-H.; Hou, X.-L. J. Org. Chem. 2003, 68, 726-730. doi:10.1021/jo025983s

32. Wu, J.; Hou, X.-L.; Dai, L.-X. J. Org. Chem. 2000, 65, 1344-1348. doi:10.1021/jo9913816

33. Hou, X.-L.; Fan, R.-H.; Dai, L.-X. J. Org. Chem. 2002, 67, 5295-5300. doi:10.1021/jo016230t

34. Liu, Y.-K.; Li, R.; Yue, L.; Li, B.-J.; Chen, Y. -C.; Wu, Y.; Ding, L.-S. Org. Lett. 2006, 8, 1521-1524. doi:10.1021/ol0529905

35. Alagiri, K.; Prabhu, K. R. Chem.-Eur. J. 2011, 17, 6922-6925. doi:10.1002/chem.201100817

36. Minakata, S.; Hotta, T.; Oderaotoshi, Y.; Komatsu, M. J. Org. Chem. 2006, 71, 7471-7472. doi:10.1021/jo061239m

37. Fan, R.-H.; Zhou, Y.-G.; Zhang, W.-X.; Hou, X.-L.; Dai, L.-X. J. Org. Chem. 2004, 69, 335-338. doi:10.1021/j0034895k

38. Kalow, J. A.; Schmitt, D. E.; Doyle, A. G. J. Org. Chem. 2012, 77, 4177-4183. doi:10.1021/jo300433a

39. Narender, M.; Surendra, K.; Srilakshmi Krishnaveni, N.; Somi Reddy, M.; Rama Rao, K. Tetrahedron Lett. 2004, 45, 7995-7997. doi:10.1016/j.tetlet.2004.09.014

40. Luo, Z.-B.; Hou, X.-L.; Dai, L.-X. Tetrahedron: Asymmetry 2007, 18, 443-446. doi:10.1016/j.tetasy.2007.02.017

41. Wang, Z.; Sun, X.; Ye, S.; Wang, W.; Wang, B.; Wu, J. Tetrahedron: Asymmetry 2008, 19, 964-969. doi:10.1016/j.tetasy.2008.03.017

42. Moss, T. A.; Fenwick, D. R.; Dixon, D. J. J. Am. Chem. Soc. 2008, 130, 10076-10077. doi:10.1021/ja8036965

43. Paixão, M. W.; Nielsen, M.; Jacobsen, C. B.; Jørgensen, K. A. Org. Biomol. Chem. 2008, 6, 3467-3470. doi:10.1039/B812369A

44. Rowland, E. B.; Rowland, G. B.; Rivera-Otero, E.; Antilla, J. C. J. Am. Chem. Soc. 2007, 129, 12084-12085. doi:10.1021/ja0751779

45. Larson, S. E.; Baso, J. C.; Li, G.; Antilla, J. C. Org. Lett. 2009, 11, 5186-5189. doi:10.1021/ol902123h

46. Della Sala, G.; Lattanzi, A. Org. Lett. 2009, 11, 3330-3333. doi:10.1021/ol901209n

47. Senatore, M.; Lattanzi, A.; Santoro, S.; Santi, C.; Della Sala, G. Org. Biomol. Chem. 2011, 9, 6205-6207. doi:10.1039/C1OB05837A

48. Della Sala, G. Tetrahedron 2013, 69, 50-56. doi:10.1016/j.tet.2012.10.068

49. Lattanzi, A.; Della Sala, G. Eur. J. Org. Chem. 2009, 1845-1848. doi:10.1002/ejoc.200900095

50. Mita, T.; Jacobsen, E. N. Synlett 2009, 1680-1684. doi:10.1055/s-0029-1217344

51. Zhang, Y.; Kee, C. W.; Lee, R.; Fu, X.; Soh, J. Y.-T.; Loh, E. M. F.; Huang, K.-W.; Tan, C.-H. Chem. Commun. 2011, 47, 3897-3899. doi:10.1039/C0CC05840H

52. Ohmatsu, K.; Hamajima, Y.; Ooi, T. J. Am. Chem. Soc. 2012, 134, 8794-8797. doi:10.1021/ja3028668

53. Chen, J.; Wu, H.; Jin, C.; Zhang, X.; Xie, Y.; Su, W. Green Chem. 2006, 8, 330-332. doi:10.1039/B600620E

54. Wang, Z.; Cui, Y.-T.; Xu, Z.-B.; Qu, J. J. Org. Chem. 2008, 73, 2270-2274. doi:10.1021/jo702401t

55. Azizi, N.; Saidi, M. R. Org. Lett. 2005, 7, 3649-3651. doi:10.1021/ol051220q

56. Torregrosa, R.; Pastor, I. M.; Yus, M. Tetrahedron 2007, 63, 469-473. doi:10.1016/j.tet.2006.10.055

57. Das, B.; Krishnaiah, M.; Thirupathi, P.; Laxminarayana, K. Tetrahedron Lett. 2007, 48, 4263-4265. doi:10.1016/j.tetlet.2007.04.062 
58. Lau, E. Y.; Newby, Z. E.; Bruice, T. C. J. Am. Chem. Soc. 2001, 123, 3350-3357. doi:10.1021/ja0037724

59. Das, B.; Reddy, V. S.; Tehseen, F.; Krishnaiah, M. Synthesis 2007, 666-668. doi:10.1055/s-2007-965921

60. Vilotijevic, I.; Jamison, T. F. Science 2007, 317, 1189-1192. doi:10.1126/science.1146421

61. Azoulay, S.; Manabe, K.; Kobayashi, S. Org. Lett. 2005, 7, 4593-4595. doi:10.1021/ol051546z

62. Kureshy, R. I.; Singh, S.; Khan, N.-u. H.; Abdi, S. H. R.; Suresh, E.; Jasra, R. V. Eur. J. Org. Chem. 2006, 1303-1309. doi:10.1002/ejoc.200500765

63. Wu, J.; Hou, X.-L.; Dai, L.-X.; Xia, L.-J.; Tang, M.-H. Tetrahedron: Asymmetry 1998, 9, 3431-3436. doi:10.1016/S0957-4166(98)00358-9

64. Kokubo, M.; Naito, T.; Kobayashi, S. Tetrahedron 2010, 66, 1111-1118. doi:10.1016/j.tet.2009.11.018

65. Gao, B.; Xie, M.; Sun, A.; Hu, X.; Ding, X.; Liu, X.; Lin, L.; Feng, X. Adv. Synth. Catal. 2012, 354, 1509-1518. doi:10.1002/adsc.201200142

66. Boudou, M.; Ogawa, C.; Kobayashi, S. Adv. Synth. Catal. 2006, 348, 2585-2589. doi:10.1002/adsc.200600290

67. Yang, M.; Zhu, C.; Yuan, F.; Huang, Y.; Pan, Y. Org. Lett. 2005, 7, 1927-1930. doi:10.1021/ol0503034

68. Matsunaga, S.; Das, J.; Roels, J.; Vogl, E. M.; Yamamoto, N.; Lida, T.; Yamaguchi, K.; Shibasaki, M. J. Am. Chem. Soc. 2000, 122, 2252-2260. doi:10.1021/ja993650f

69. Arai, K.; Salter, M. M.; Yamashita, Y.; Kobayashi, S. Angew. Chem., Int. Ed. 2007, 46, 955-957. doi:10.1002/anie.200603787

70. Chen, Y.-J.; Chen, C. Tetrahedron: Asymmetry 2007, 18, 1313-1319. doi:10.1016/j.tetasy.2007.04.030

71. Gansäuer, A.; Fan, C.-A.; Keller, F.; Karbaum, P. Chem.-Eur. J. 2007, 13, 8084-8090. doi:10.1002/chem.200701021

72. Belokon, Y. N.; Chusov, D.; Peregudov, A. S.; Yashkina, L. V.; Timofeeva, G. I.; Maleev, V. I.; North, M.; Kagan, H. B. Adv. Synth. Catal. 2009, 351, 3157-3167. doi:10.1002/adsc.200900523

73. Bao, H.; Wu, J.; Li, H.; Wang, Z.; You, T.; Ding, K. Eur. J. Org. Chem. 2010, 35, 6722-6726. doi:10.1002/ejoc.201001222 See for the Mg-catalyzed enantioselective desymmetrization of meso-epoxides.

74. Plancq, B.; Ollevier, T. Chem. Commun. 2012, 48, 3806-3808. doi:10.1039/C2CC18032D

See for the Fe-catalyzed enantioselective desymmetrization of meso-epoxides.

75. Bao, H.; Zhou, J.; Wang, Z.; Guo, Y.; You, T.; Zhang, H.; Ding, K. J. Am. Chem. Soc. 2008, 130, 10116-10127. doi:10.1021/ja801847r See for the Ti-catalyzed enantioselective desymmetrization of meso-epoxides.

76. Hu, X.; Gao, B.; Chu, Y.; Li, W.; Liu, X.; Lin, L.; Feng, X. Chem.-Eur. J. 2012, 18, 3473-3477. doi:10.1002/chem.201103792 See for the Sc-catalyzed enantioselective desymmetrization of meso-epoxides.

77. Beaver, M. G.; Jamison, T. F. Org. Lett. 2011, 13, 4140-4143. doi:10.1021/ol201702a See for the Ni-catalyzed ring-opening of meso-epoxides.

78. Andrews, G. C.; Crawford, T. C.; Contillo, L. G., Jr. Tetrahedron Lett. 1981, 22, 3803-3806. doi:10.1016/S0040-4039(01)91312-7

79. Garrett, C. E.; Fu, G. C. J. Org. Chem. 1997, 62, 4534-4535. doi:10.1021/jo970419g
80. Paek, S. H.; Shim, S. C.; Cho, C. S.; Kim, T.-J. Synlett 2003, 849-851. doi:10.1055/s-2003-38758

81. Pietrusiewicz, K. M.; Koprowski, M.; Pakulski, Z. Tetrahedron: Asymmetry 2002, 13, 1017-1019. doi:10.1016/S0957-4166(02)00245-8

82. Denmark, S. E.; Barsanti, P. A.; Wong, K.-T.; Stavenger, R. A. J. Org. Chem. 1998, 63, 2428-2429. doi:10.1021/jo9801420

83. Tokuoka, E.; Kotani, S.; Matsunaga, H.; Ishizuka, T.; Hashimoto, S.; Nakajima, M. Tetrahedron: Asymmetry 2005, 16, 2391-2392. doi:10.1016/j.tetasy.2005.06.021

84. Kotani, S.; Furusho, H.; Sugiura, M.; Nakajima, M. Tetrahedron 2013, 69, 3075-3081. doi:10.1016/j.tet.2013.01.066

85. Simonini, V.; Benaglia, M.; Benincori, T. Adv. Synth. Catal. 2008, 350, 561-564. doi:10.1002/adsc.200700564

86. Pu, X.; Qi, X.; Ready, J. M. J. Am. Chem. Soc. 2009, 131, 10364-10365. doi:10.1021/ja9041127

87. Tao, B.; Lo, M. M.-C.; Fu, G. C. J. Am. Chem. Soc. 2001, 123, 353-354. doi:10.1021/ja003573k

88. Nakajima, M.; Saito, M.; Uemura, M.; Hashimoto, S. Tetrahedron Lett. 2002, 43, 8827-8829. doi:10.1016/S0040-4039(02)02229-3

89. Chelucci, G.; Baldino, S.; Pinna, G. A.; Benaglia, M.; Buffa, L.; Guizzettie, S. Tetrahedron 2008, 64, 7574-7582. doi:10.1016/j.tet.2008.05.105

90. Takenaka, N.; Sarangthem, R. S.; Captain, B. Angew. Chem., Int. Ed. 2008, 47, 9708-9710. doi:10.1002/anie.200803338

91. Malkov, A. V.; Gordon, M. R.; Stončius, S.; Hussain, J.; Kočovský, P. Org. Lett. 2009, 11, 5390-5393. doi:10.1021/ol902148s

92. Hayashi, M.; Shiomi, N.; Funahashi, Y.; Nakamura, S. J. Am. Chem. Soc. 2012, 134, 19366-19369. doi:10.1021/ja309963w

93. Wang, Z.; Chen, Z.; Sun, J. Angew. Chem., Int. Ed. 2013, 52, 6685-6688. doi:10.1002/anie.201300188

94. Chawla, R.; Singh, A. K.; Yadav, L. D. S. RSC Adv. 2013, 3, 11385-11403. doi:10.1039/C3RA00175J

95. Cao, Y.-M.; Zhang, F.-T.; Shen, F.-F.; Wang, R. Chem.-Eur. J. 2013, 19, 9476-9480. doi:10.1002/chem.201300297

\section{License and Terms}

This is an Open Access article under the terms of the Creative Commons Attribution License (http://creativecommons.org/licenses/by/2.0), which permits unrestricted use, distribution, and reproduction in any medium, provided the original work is properly cited.

The license is subject to the Beilstein Journal of Organic Chemistry terms and conditions:

(http://www.beilstein-journals.org/bjoc)

The definitive version of this article is the electronic one which can be found at: $\underline{\text { doi:10.3762/bjoc. } 9.192}$ 